\title{
المناهج النصيتة في النقد العربي الحديث
}

د. محمد الحسن ولد محمد المصطفى

أستاذ النقل الأدبي ومناهجه

جامعة نو اكشوط - موريتانيا

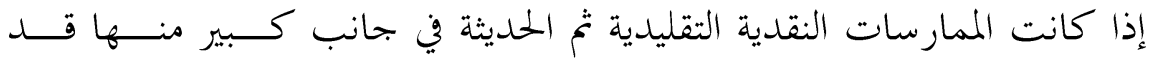

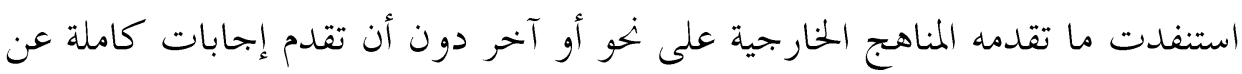

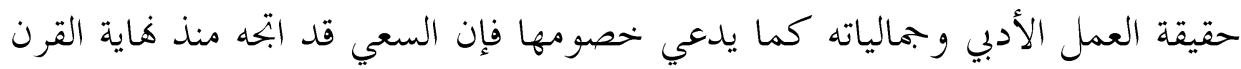

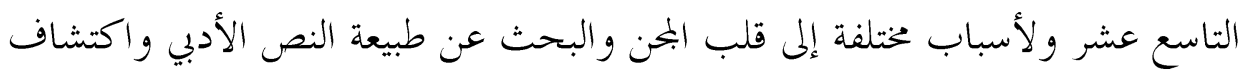

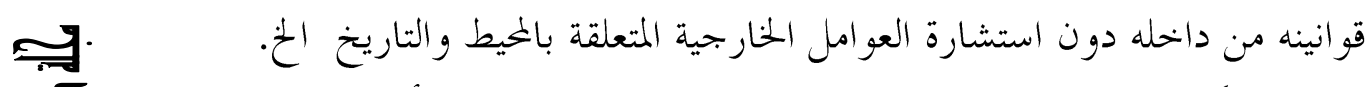

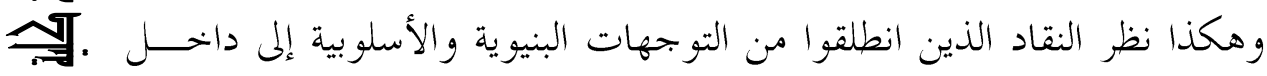

النص، مترصدين تفاعلات اللغة مع عملية الإبداع الإنساني.

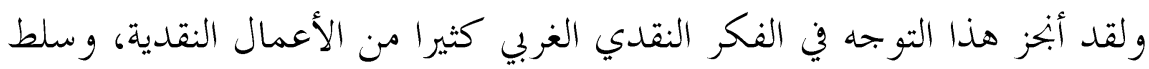

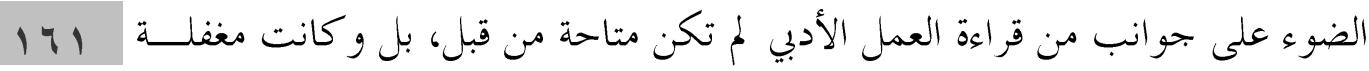

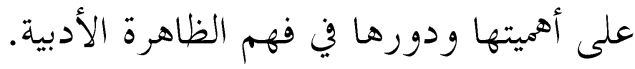

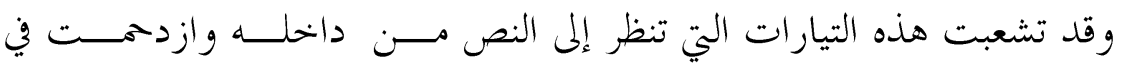

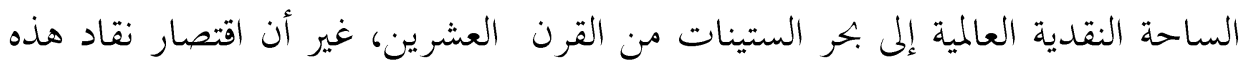

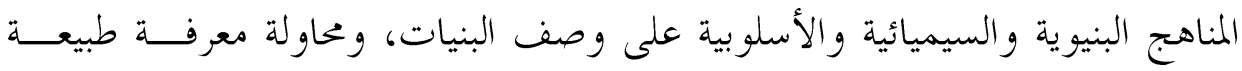

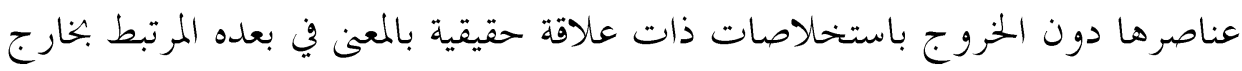

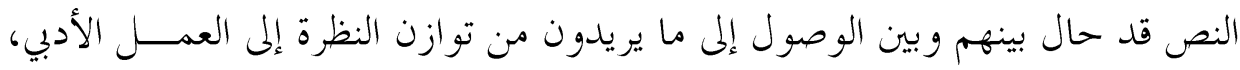

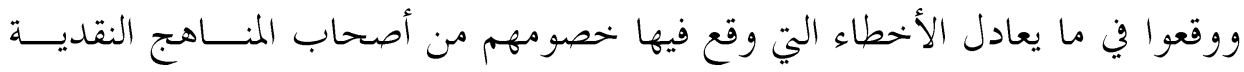

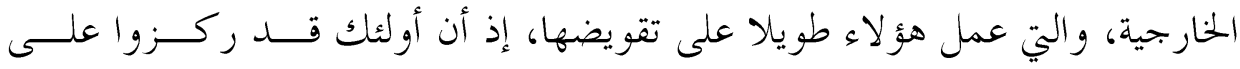

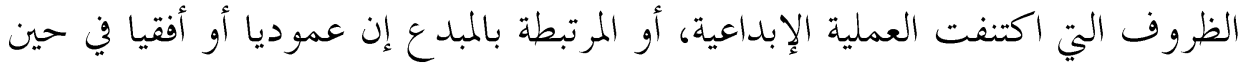

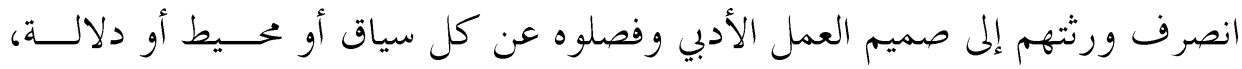




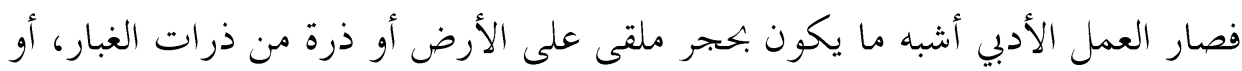

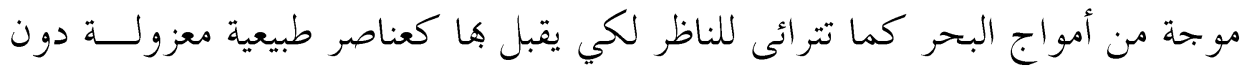
أن يفكر في ربطها بعد النظر إليها في ذاتا بسياقاتحا الطبيعية الأكبر.

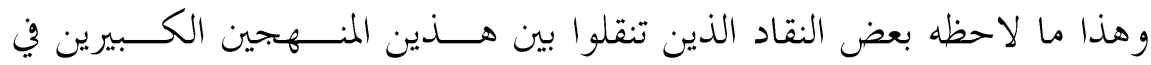

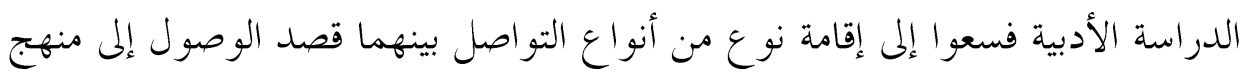

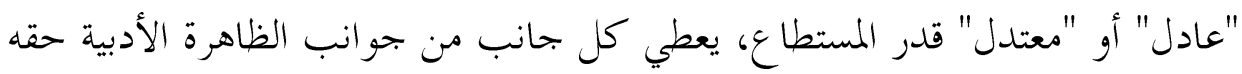

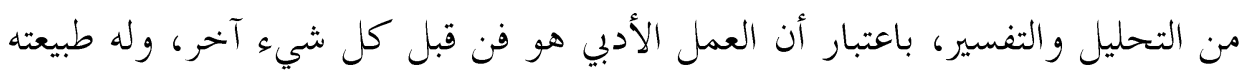

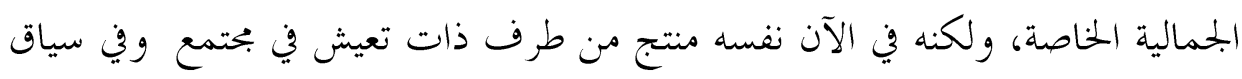
تاريخي متر اكمب، ومر سل إلى قارئ مهتم.

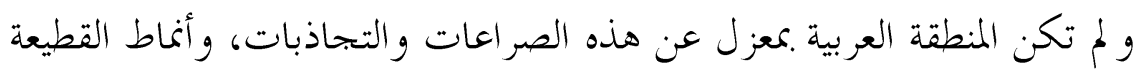

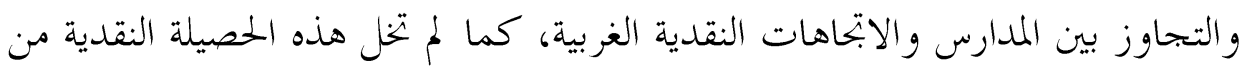

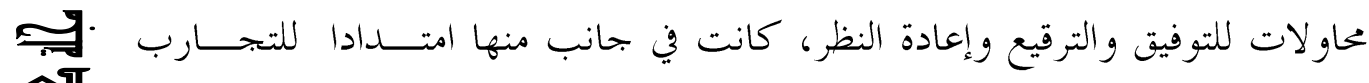

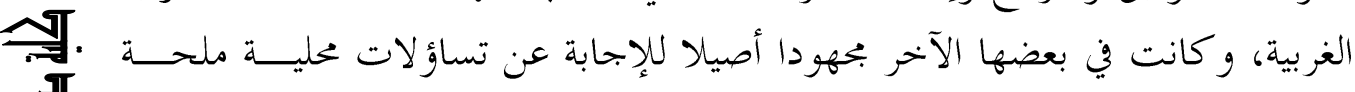

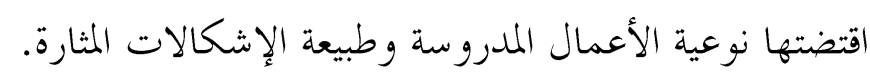

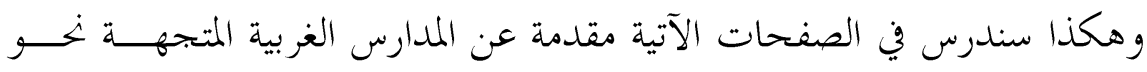

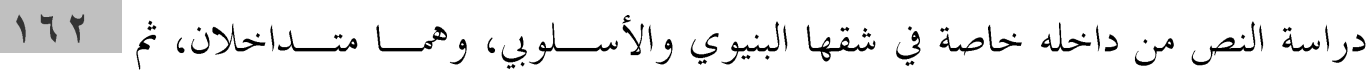

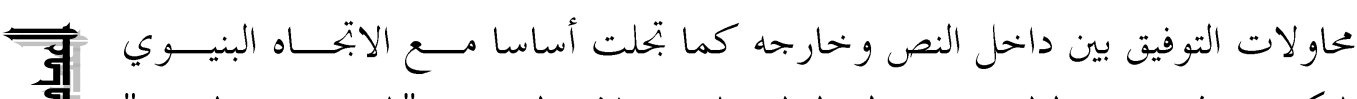

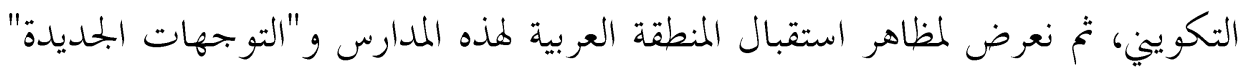
في النقد الأدبي.

\section{أولا: البنيويته والمناهج الندي. النصيتة المجاورة:}

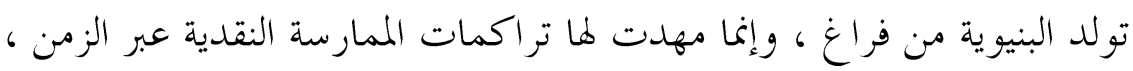

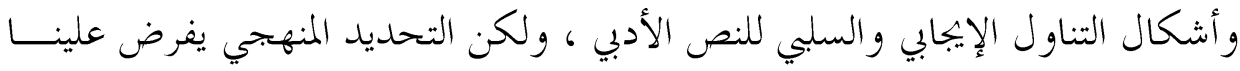

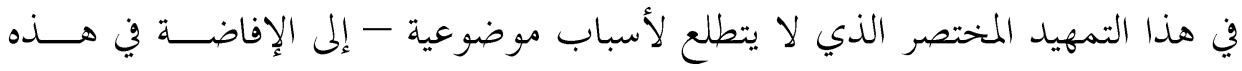

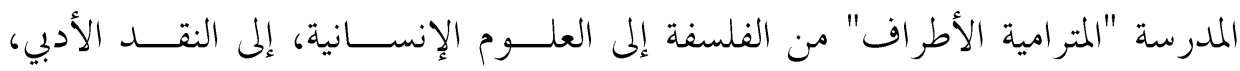

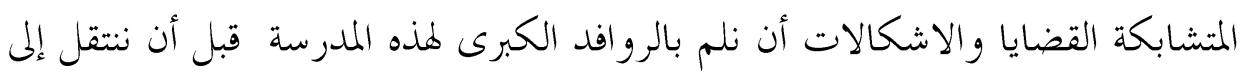

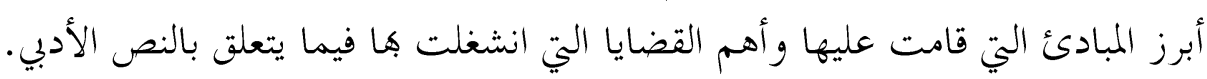




\section{أروافد البنيويتة:}

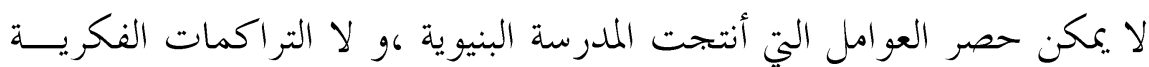

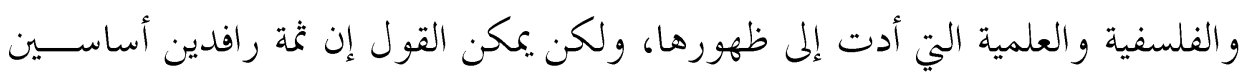

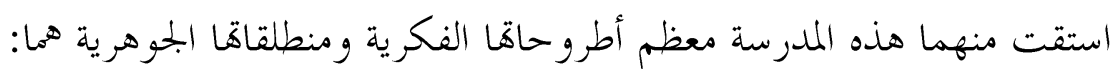

\section{أ - سوسير والتأسيس للسانيات المعاصرة:}

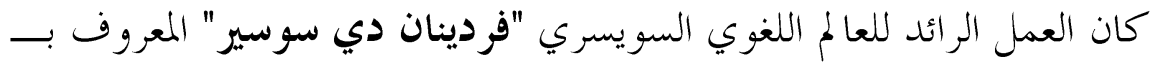

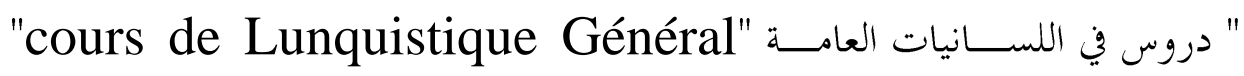

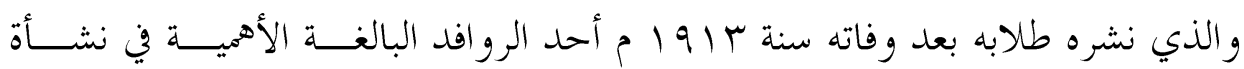

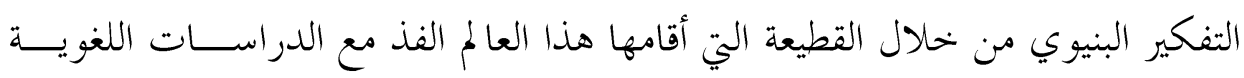
السالفة عليه.

فقد عرض لأول مرة بحموعة من المفاهيم والآليات التي أثبتت كفاءها في الدرس التبه

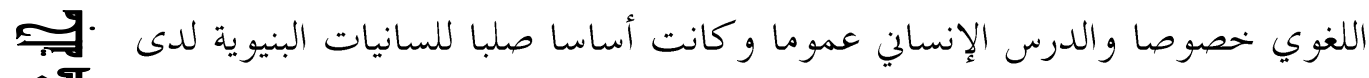
궉. هلمسلايف، وجاكبسون، ومارتيني، وغيرهم ناهيك عن الاتحاهات التي قامت علــى أنقاض اللسانيات البنيوية .

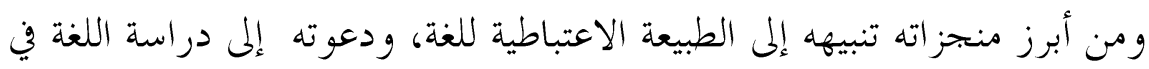

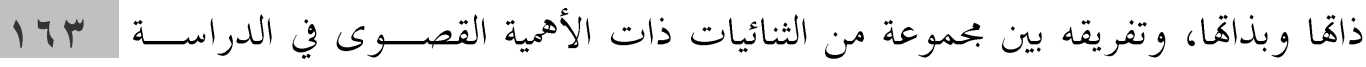

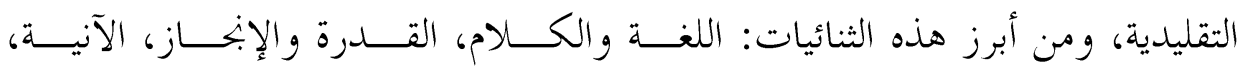

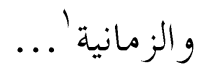

لقد ساهم سوسير بالفعل " من خحلال المثال الذي قدمه، والأفكار "التنبئية" التي

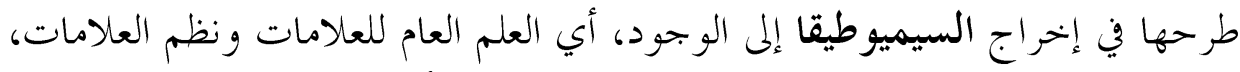

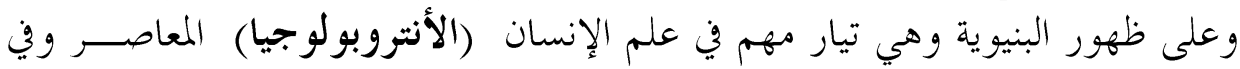

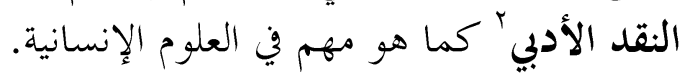

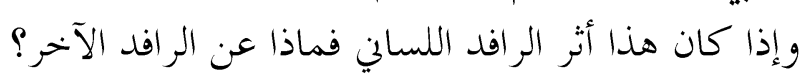

\section{ب-الشكانليون الروس:}

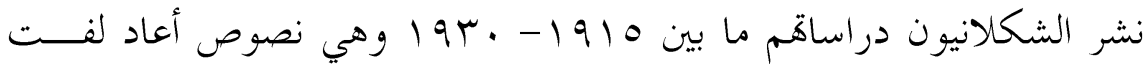

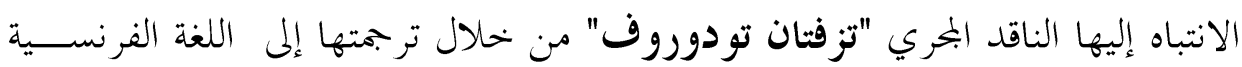


ووصف هؤلاء النقاد -الذين كانوا على خلاف فكري مع الثـــورة البلشـفية

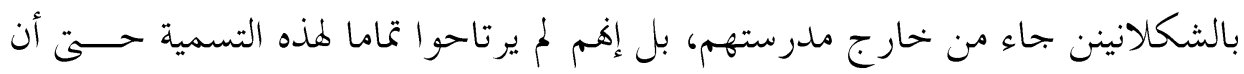

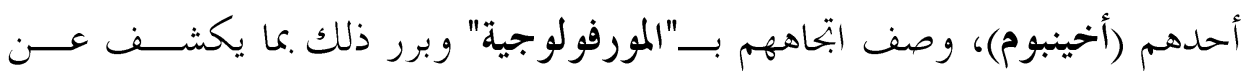

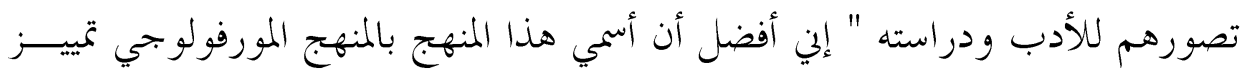

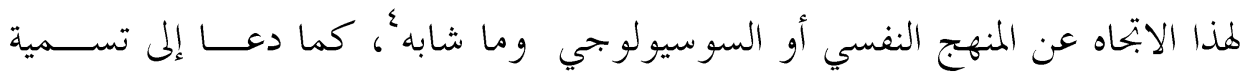

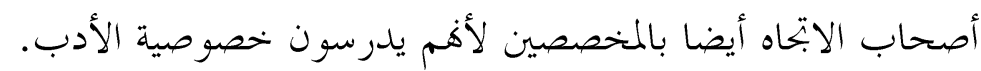

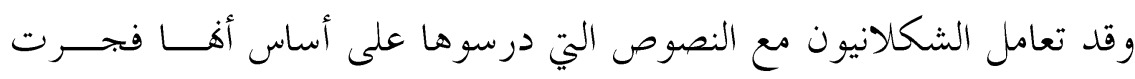

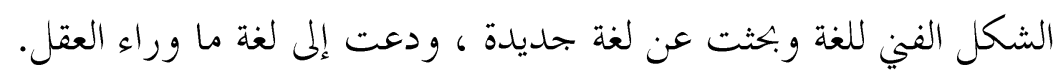

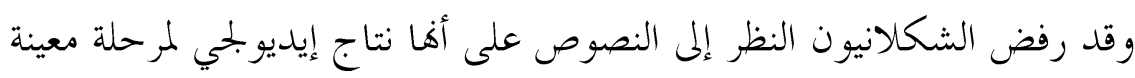

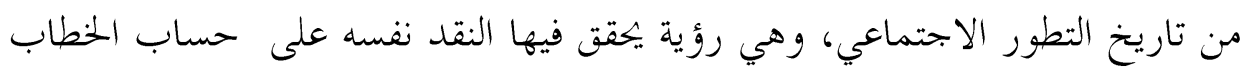

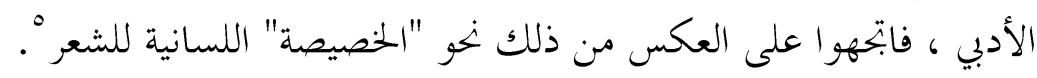

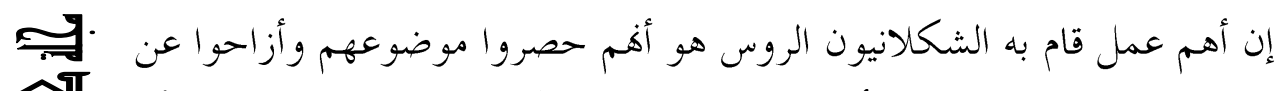

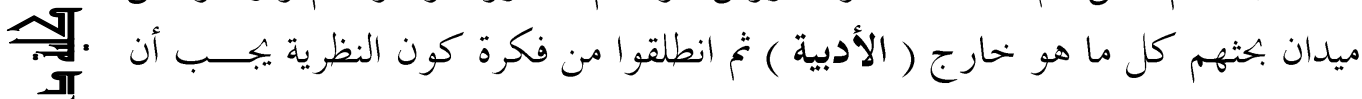
$\frac{\pi}{3}$

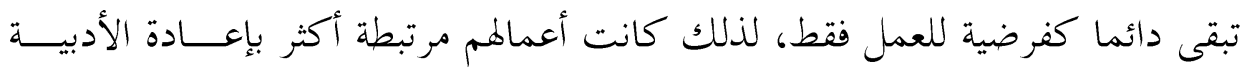

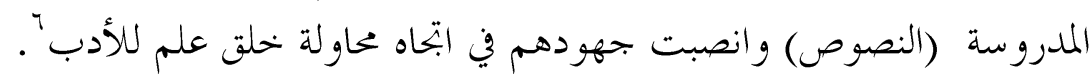

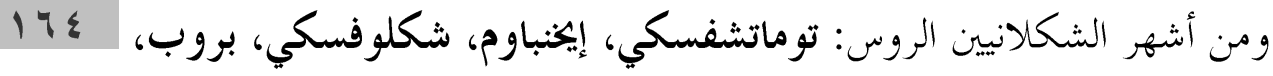

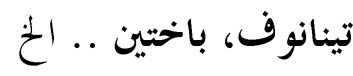
"ثخ امتدت تأثيرات هذه المغامرة الروسية الكبيرة بفرعها الشكلي لا الباختيني إلى

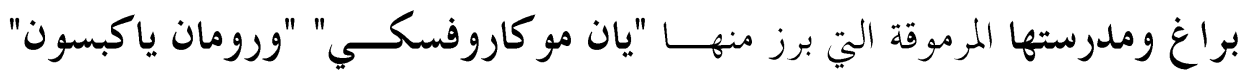
فطور مكاروفسكي الأساس الإشاري المكثف لتطوير نقد المسرح و العلامة المســـرحية

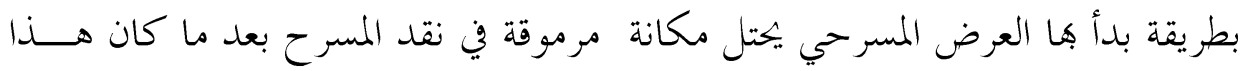

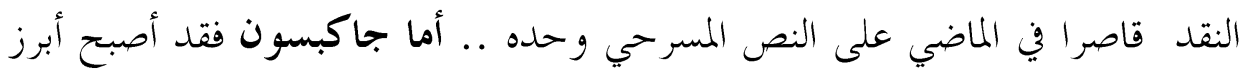

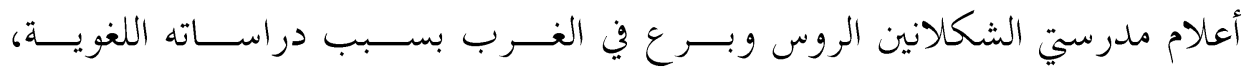
واستقصاءاته المهمة عن عمل اللغة و آليات عملية التوصيل من ناحية، وتطبيق هذا كله فئل

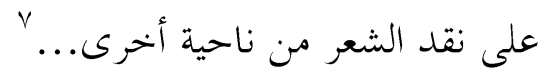




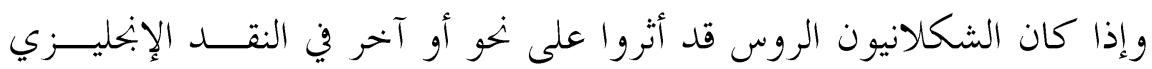

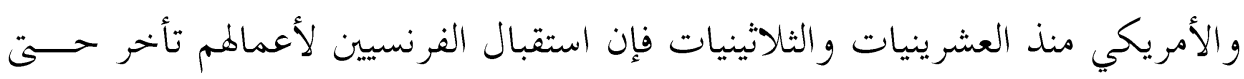

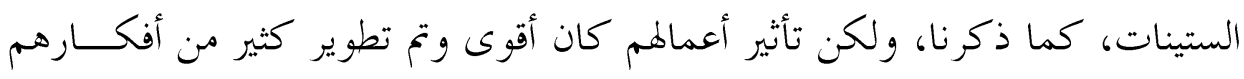

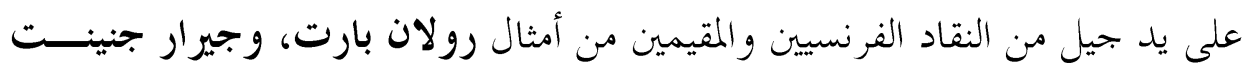

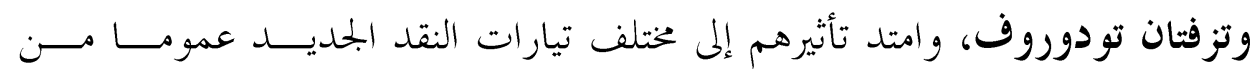
سيميائية وأسلو بية وتفكيكية وغيرها.

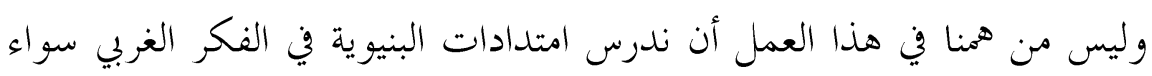

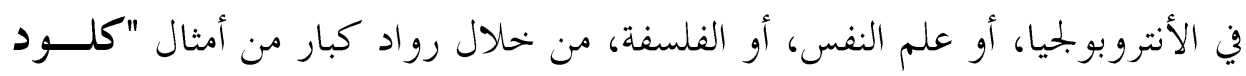

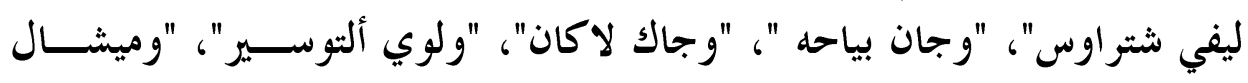
فو كو" وغيرهم.

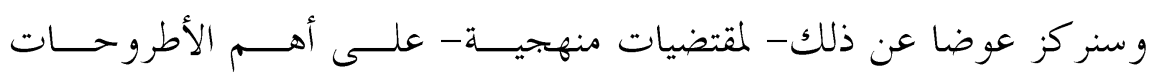

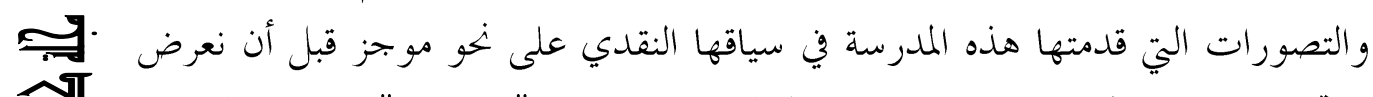

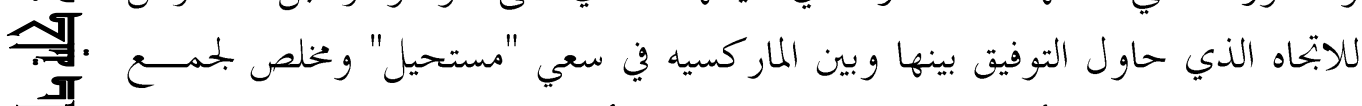
$\frac{\pi}{3}$

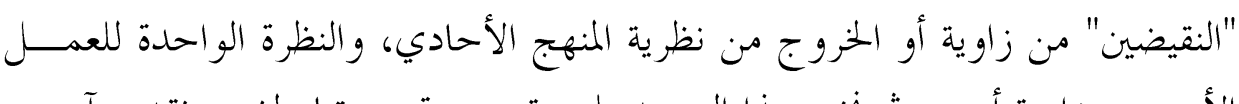

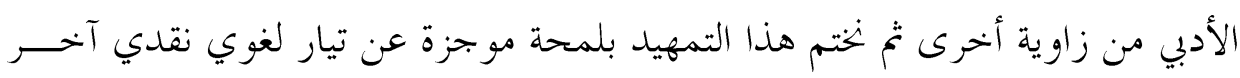

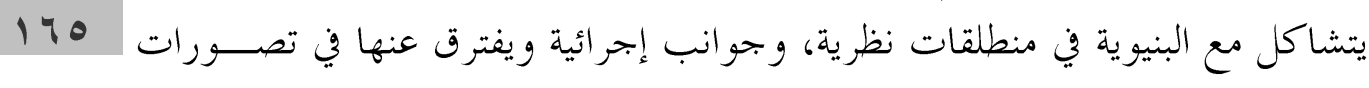
وزوايا أخرى من الدراسة الأدبية.

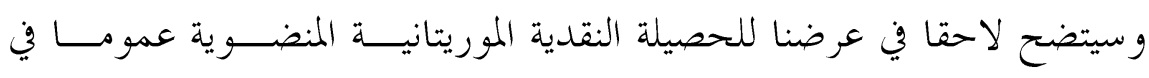

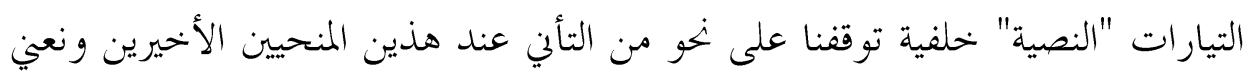

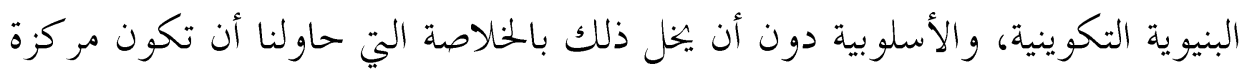

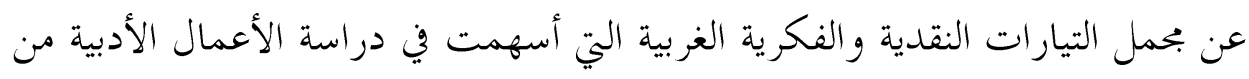
منظور داخل النص جزئيا أو كليا.

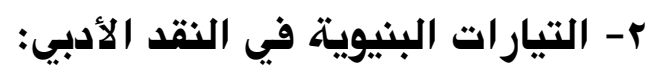
أ - البنيوية (الوصفيةأو الشكلية):

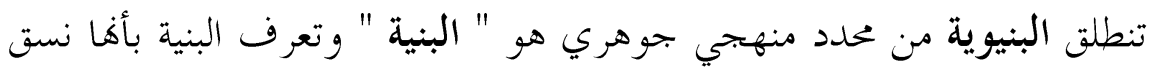

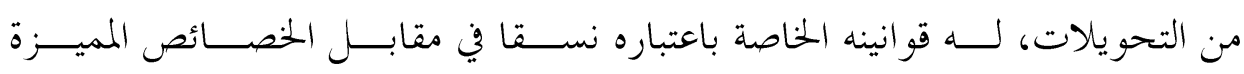




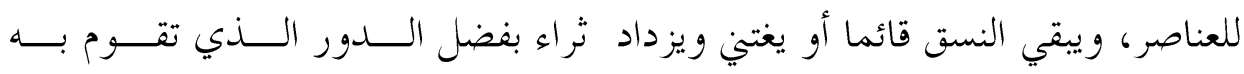

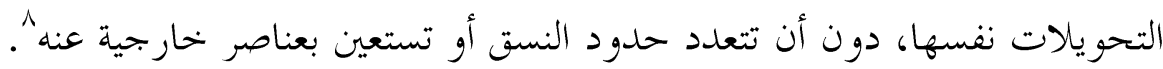

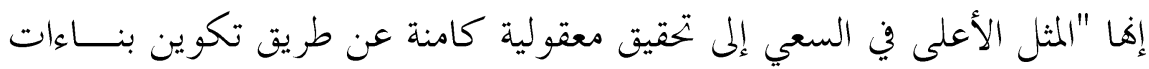

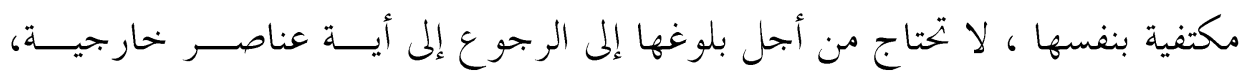

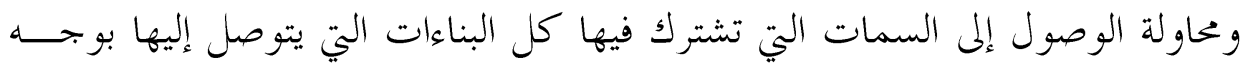
عامج

ويمكن أن ناحظ ثلاث صفات محددة للبنية تتمثل في أها:

$$
\text { r }
$$

"وقد شب جدل حول مفهوم مصطلح البنية باعتباره تصورا ذهنيا بحردا وليس

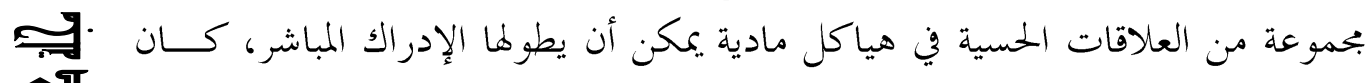

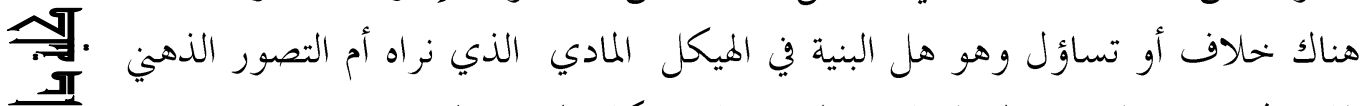

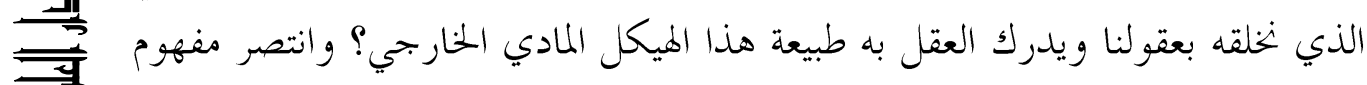

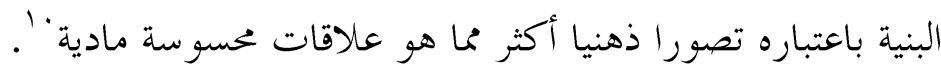

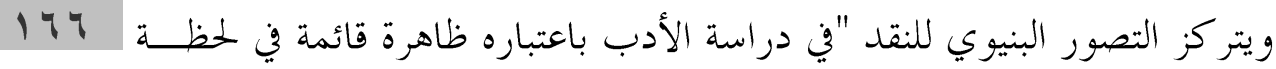

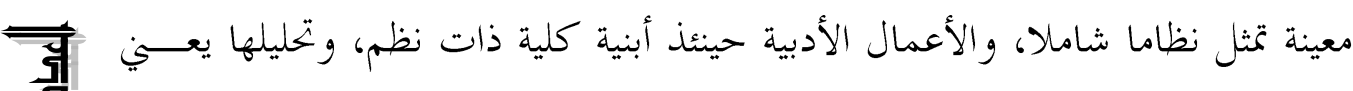

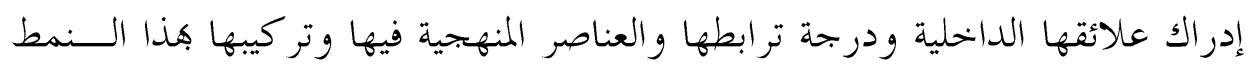
الذي تؤدي به وظائفها الجمالية المتعددة.

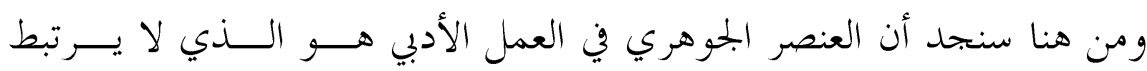

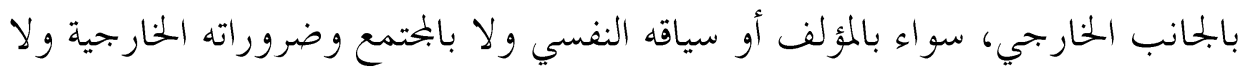

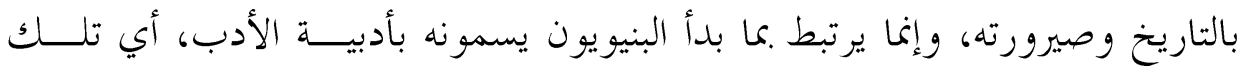

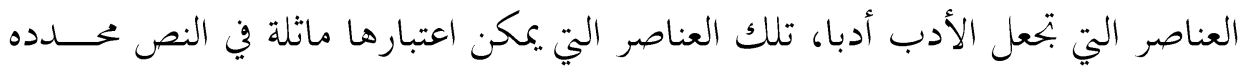
لجنسه الفني ومكيفة لطبيعة تكوينه وموجهة لمدى كفاءته في أداء وظيفته الجمالية على لئل

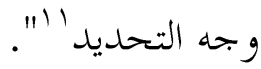


وقد أدى همم هذا التوجه إلى التركيز على النص، وقدر اته على تقديم نفسه على

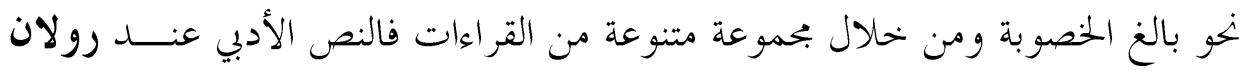

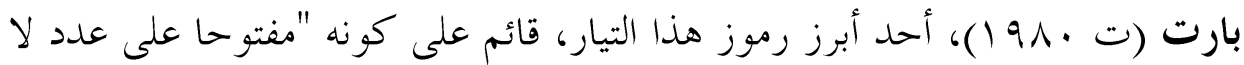

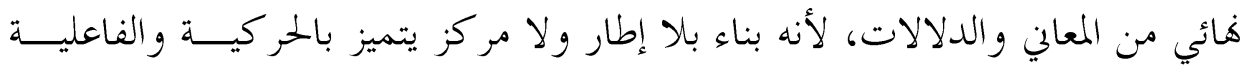

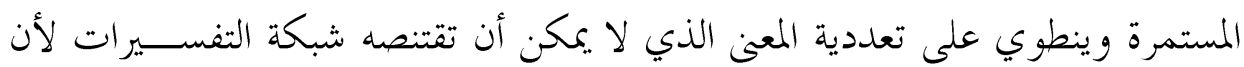

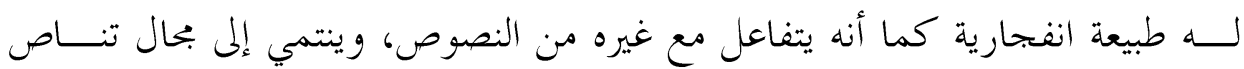

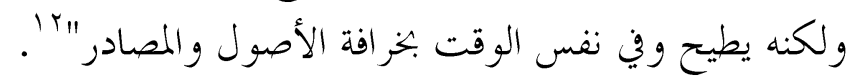

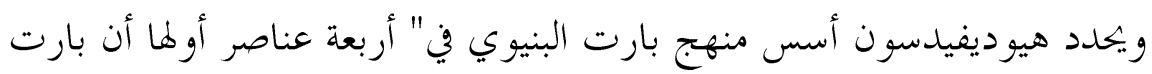

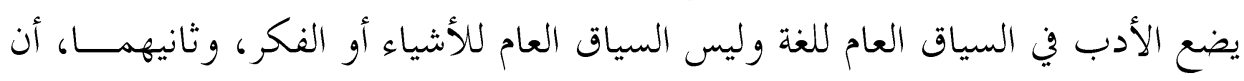

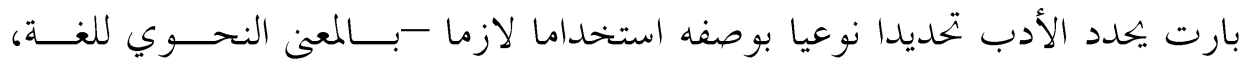

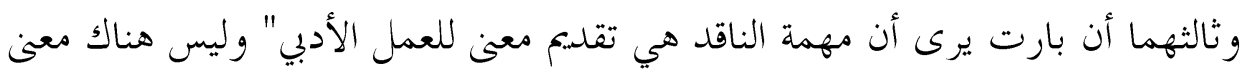

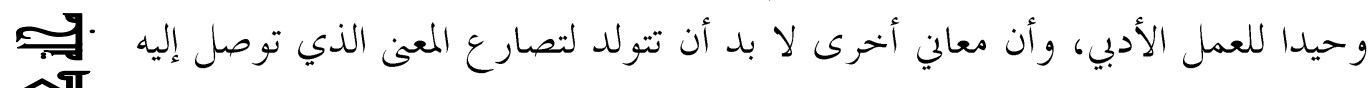
\begin{tabular}{l} 
ज्ञ. \\
$\frac{\pi}{3}$ \\
\hline$=\frac{4}{3}$
\end{tabular}

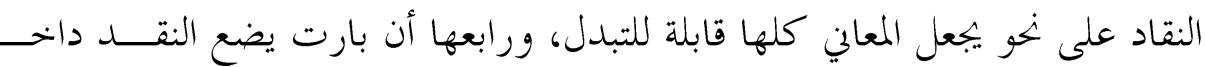

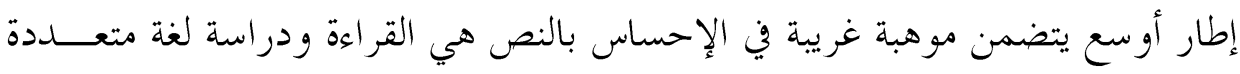

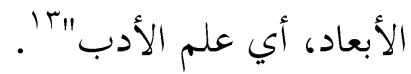

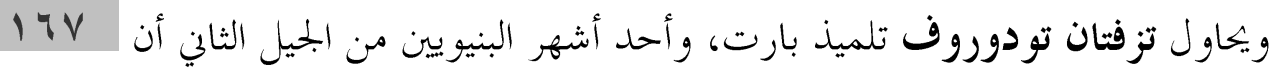

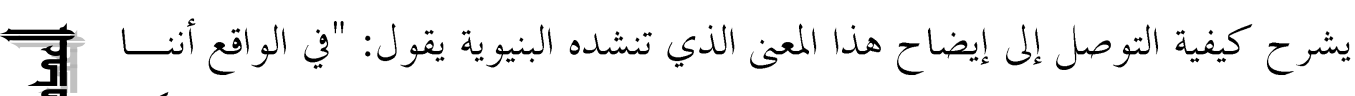

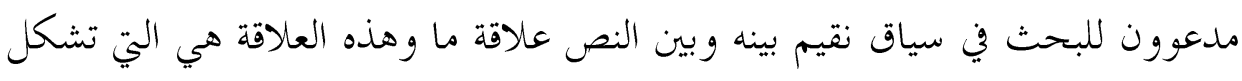

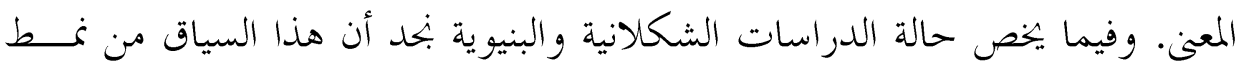

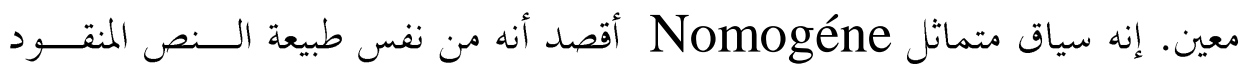

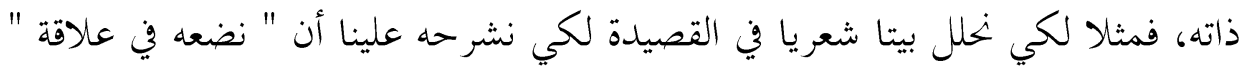

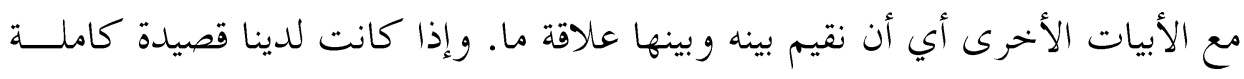

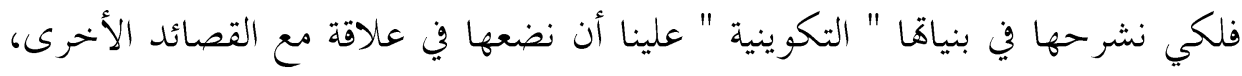

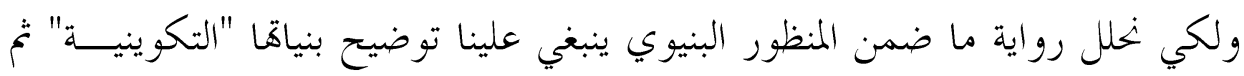

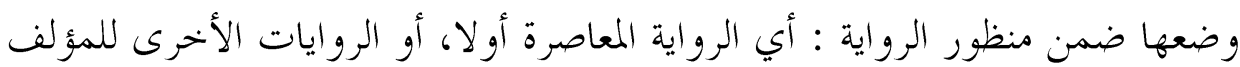




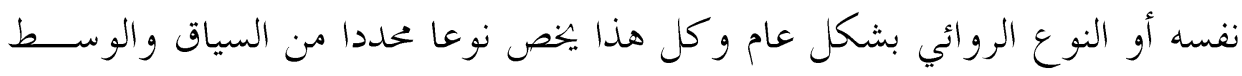

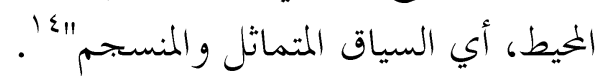

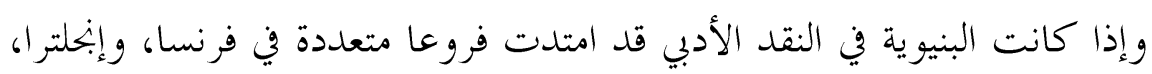

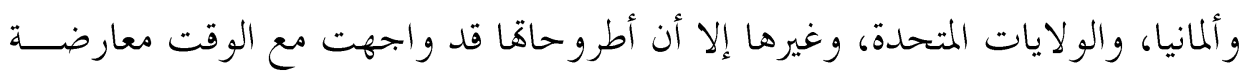

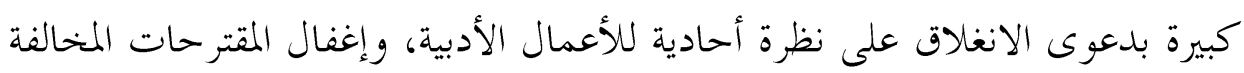

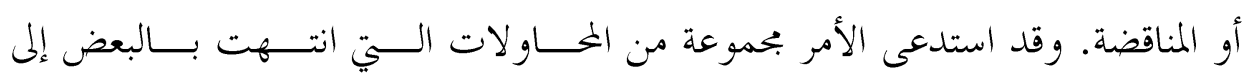

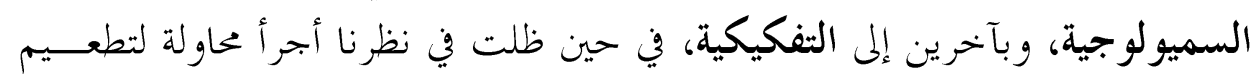

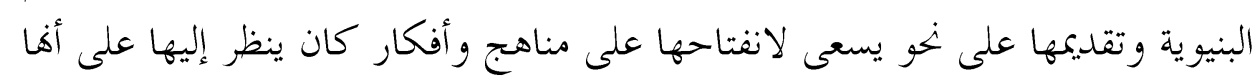

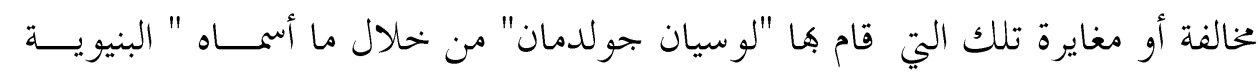

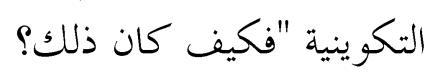

ب- البنيوية التكوينية وهاجس القراءة "المكتلمة" المكان

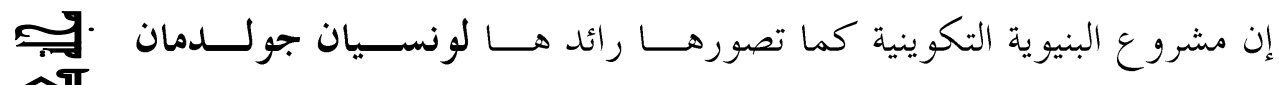

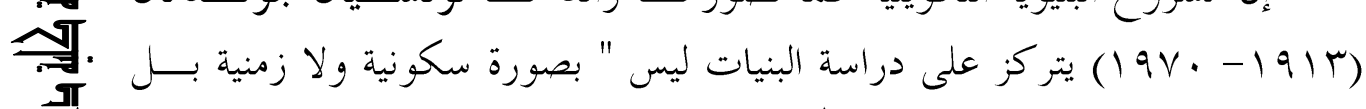

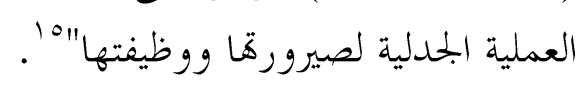

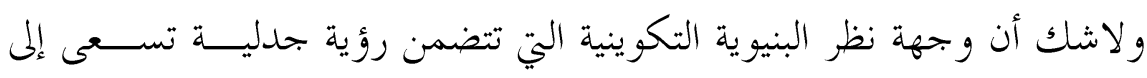

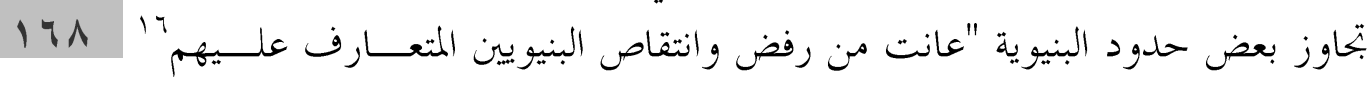

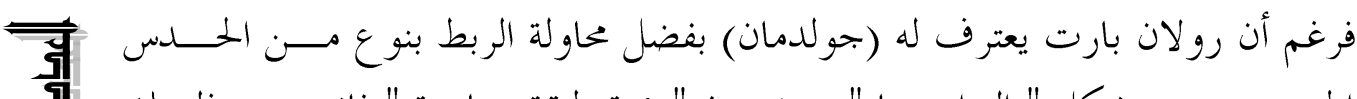

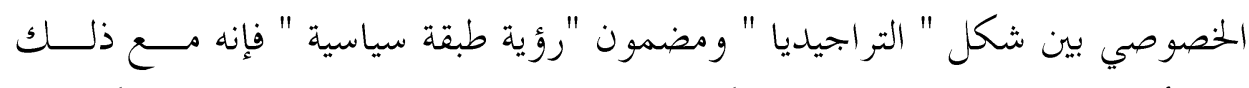

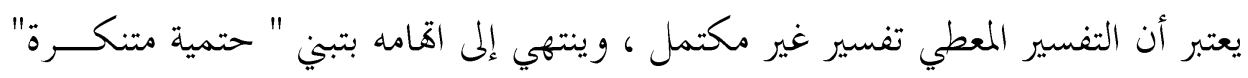

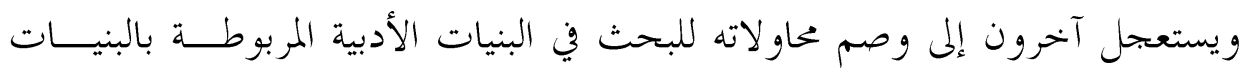

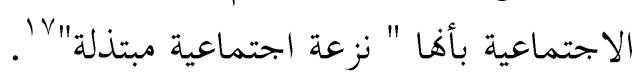

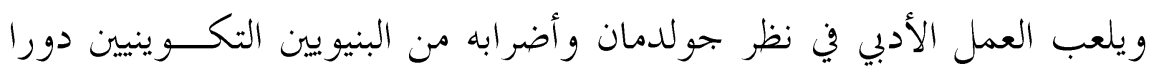

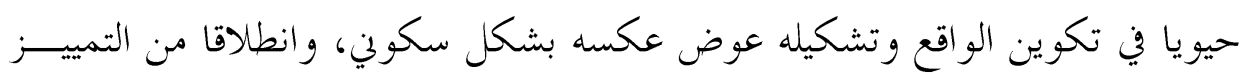

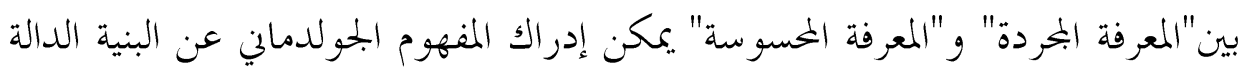

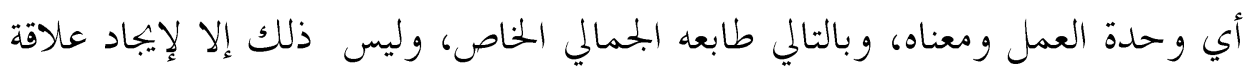


مشتركة ليست بين مضمون الوعي الجمعي ومضمون العمل الأدبي، ولكن بين الـــبين

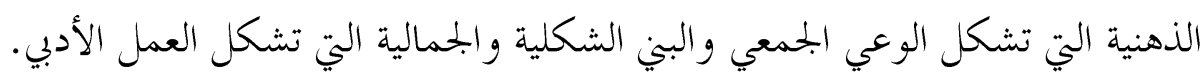

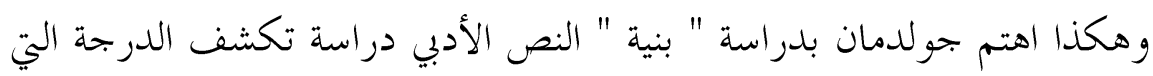

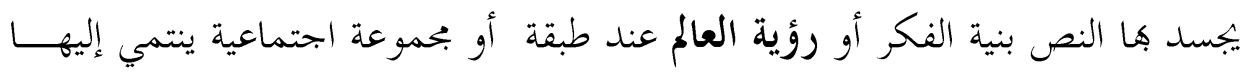

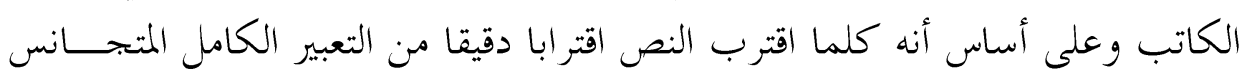

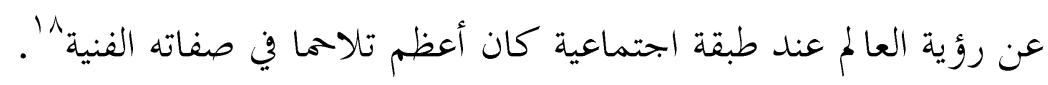

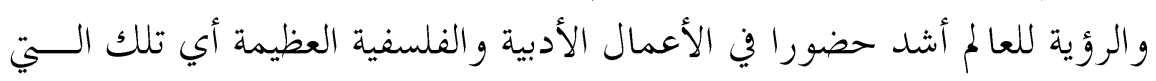

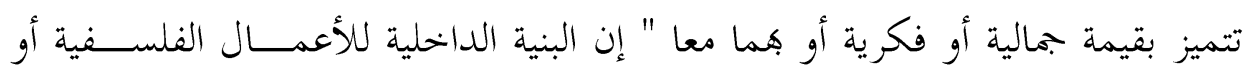
الأدبية أو الفنية العظمى صادرة عن كون هاته الأعمال تعبر في مستوى يتمتع بانسجام

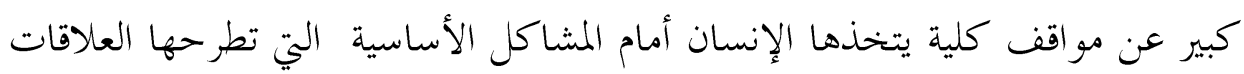

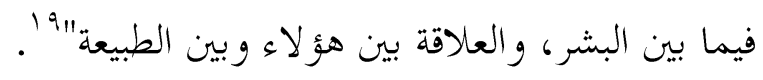

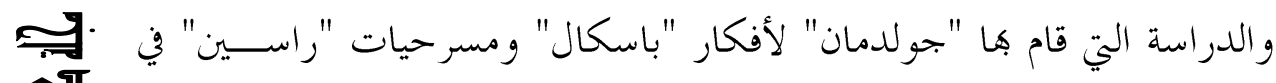

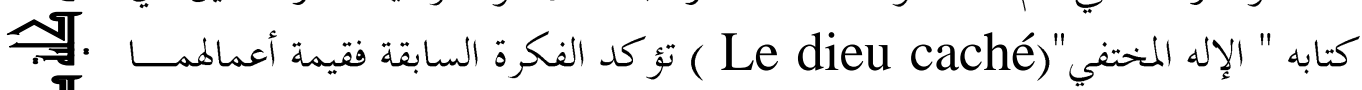
$\frac{\pi}{\frac{\pi}{3}}$

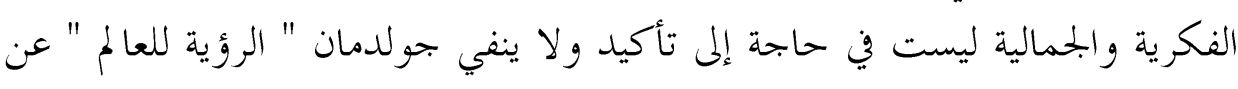

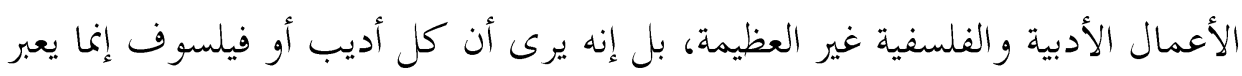

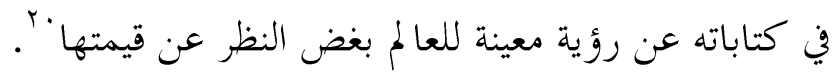

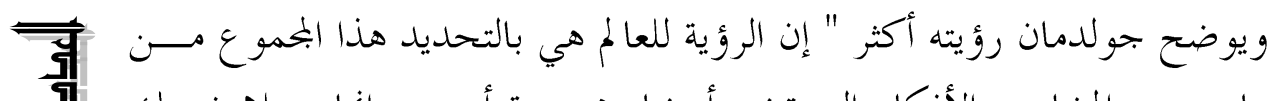

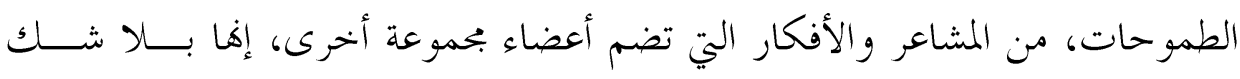

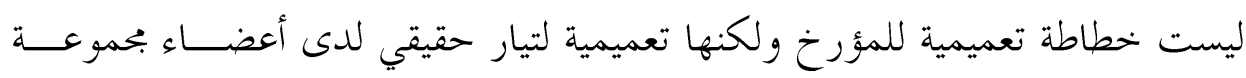

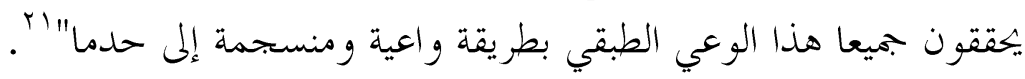

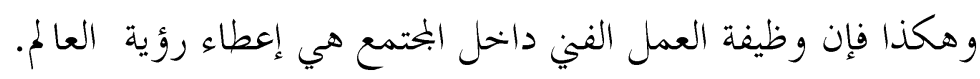

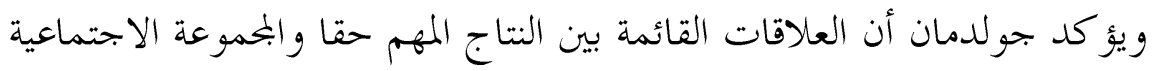

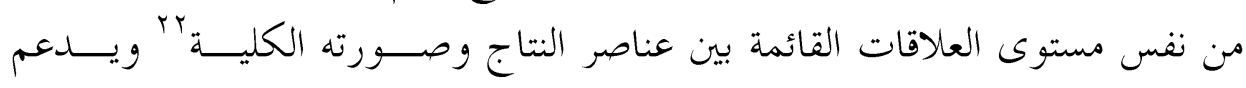
جولدمان وجهة نظره بالملاحظات التالية: ا-أن العلاقة الجوهرية بين الحياة الاجتماعية والإبداع الأدبي لا تتعلق بضمون

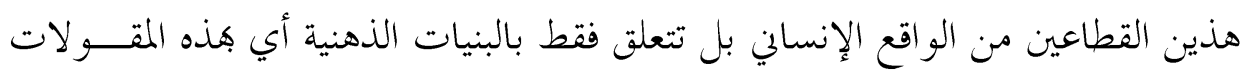


التي تنظم في نفس الوقت الوعي التجريي بلمموعة اجتماعية والعالم المتخيل المبدع من

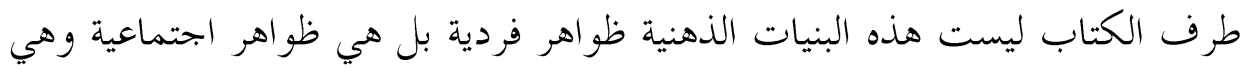

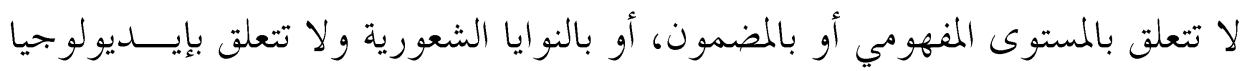

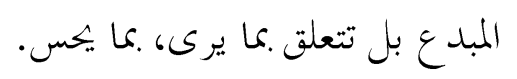

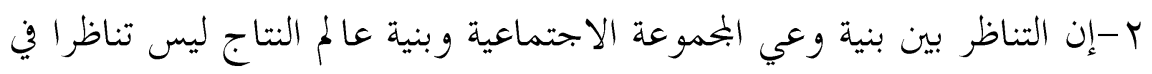

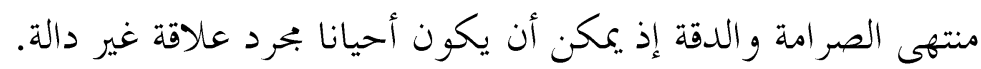

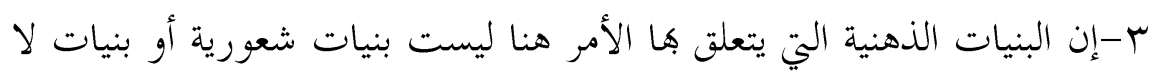

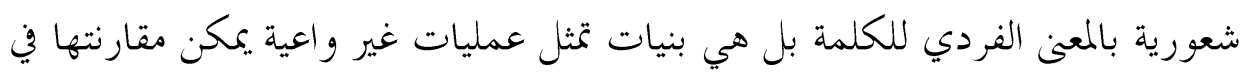

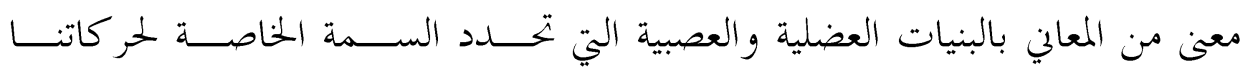

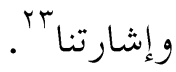

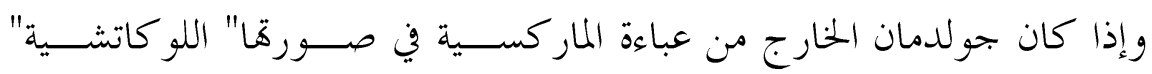

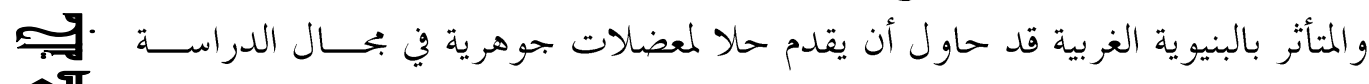

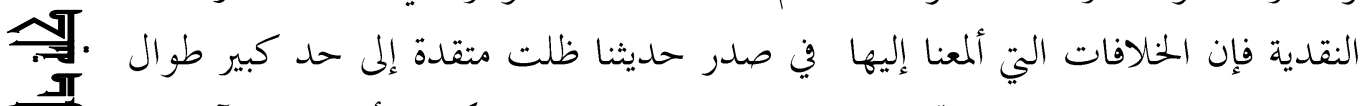
$\frac{\pi}{3}$

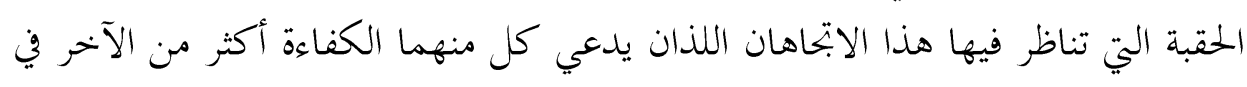

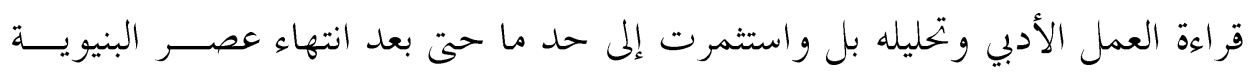
وتوهجها وموضويتها في الغرب.

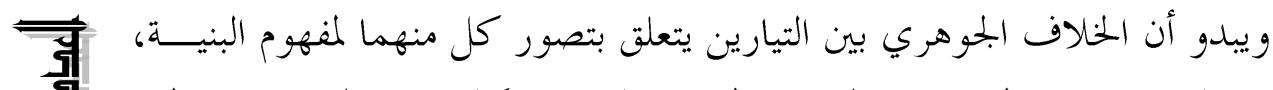

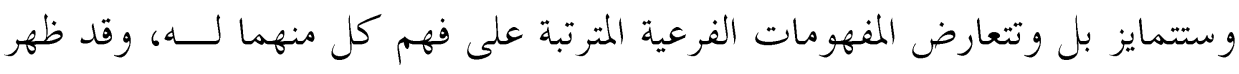

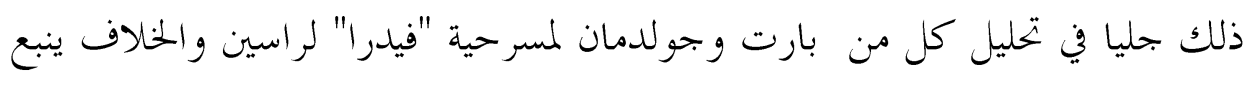

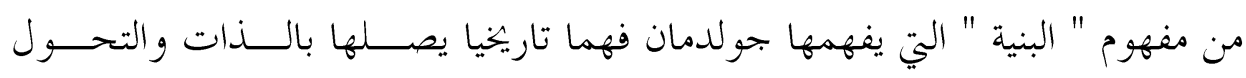

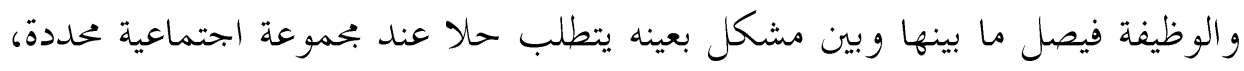

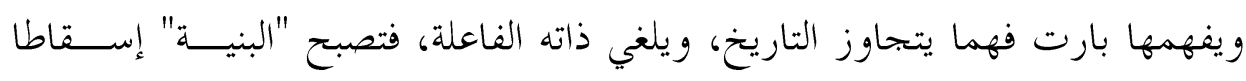

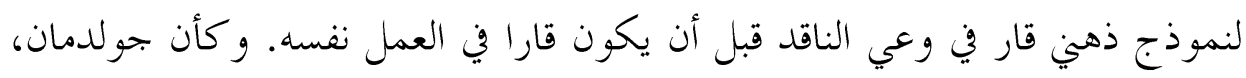

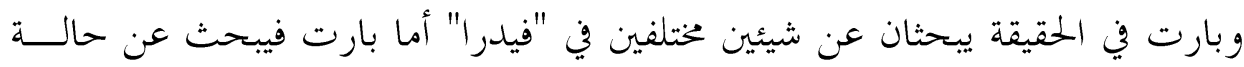

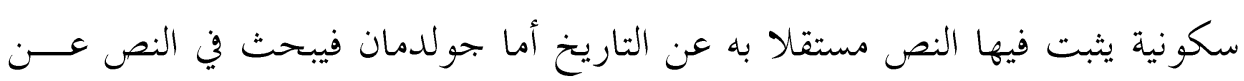


التلاحم الداخلي الذي يربط بين الأجزاء و الكل من حيث تحقيقه لوظيفة على مستوى

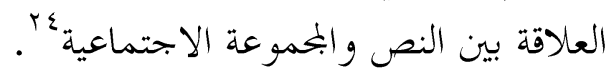

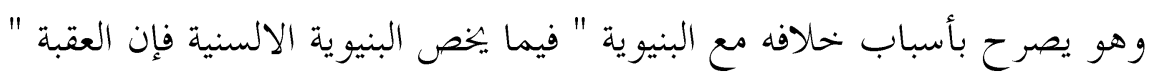

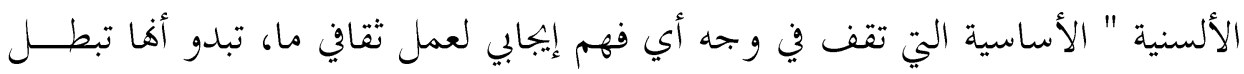

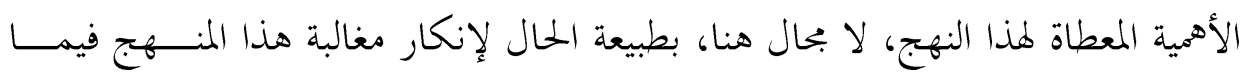

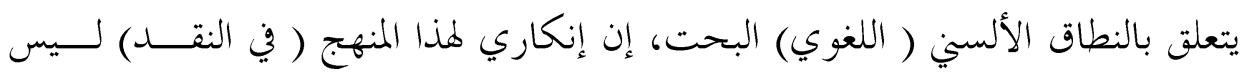

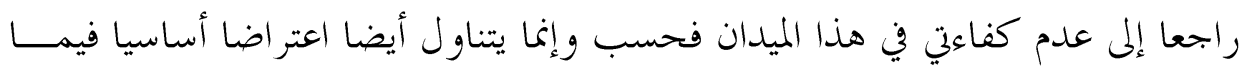

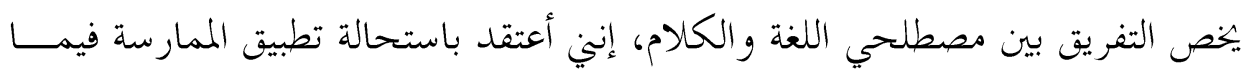

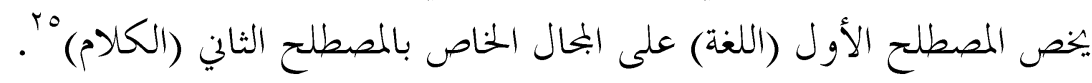

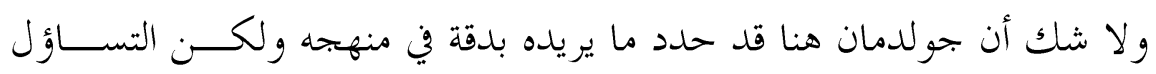

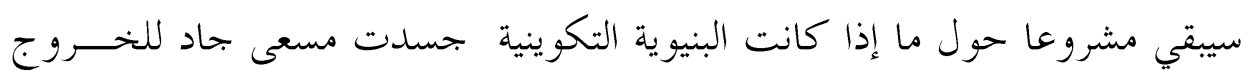
من "شرنقة" التحليل اللغوي "المغلق"، أم أها كانت محاولة خحاقة " لنتقيع الماركسية. 궉.

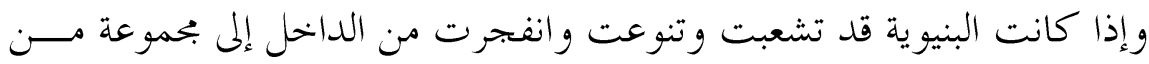

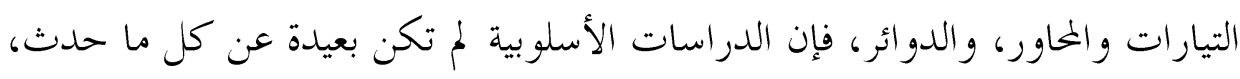

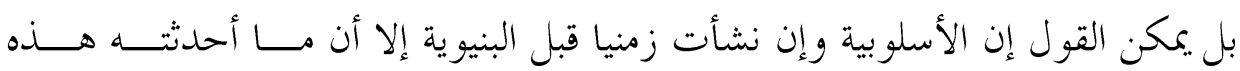

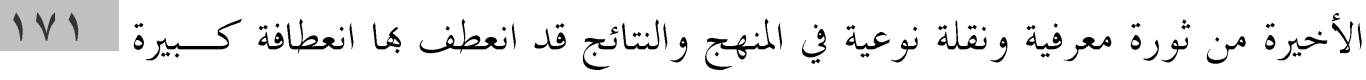
عن الخط التقليدي الذي سارت عليه ردحا من ونس الزمن.

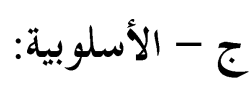
لقد نشأت الدراسات الأسلوبية غير بعيدة من البنيوية ، ووفي كنف المنجــزات

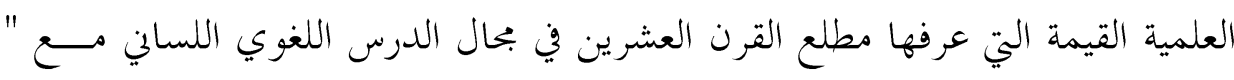

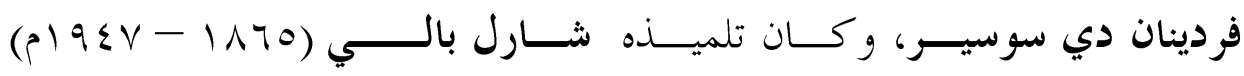

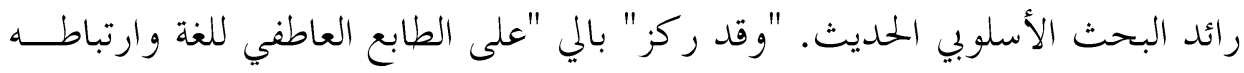

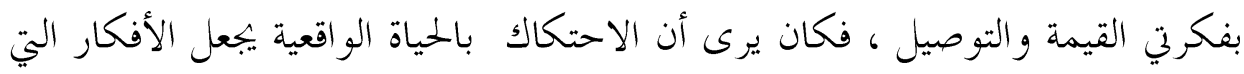

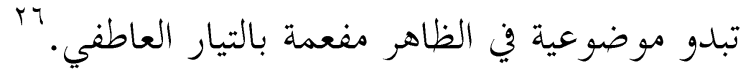




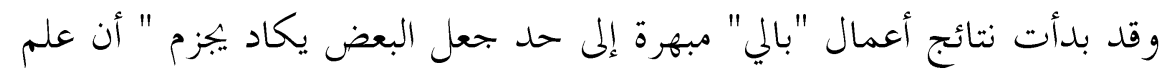

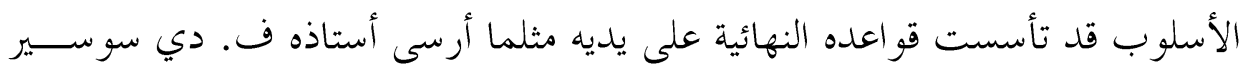

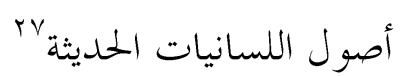

وعلى كل حال فقد انطلقت الأسلوبية من بعده تيارات شتى وتصورات خختلفة

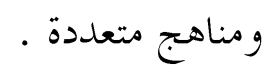

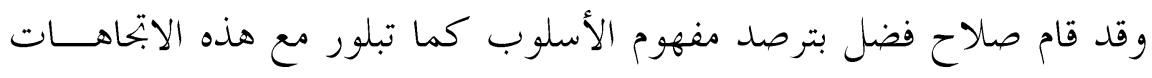

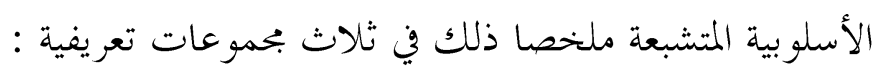

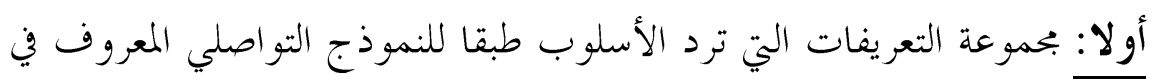

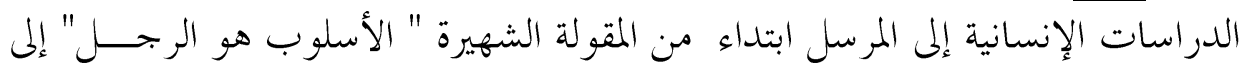

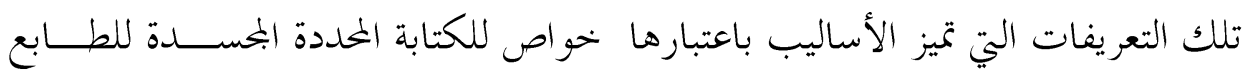

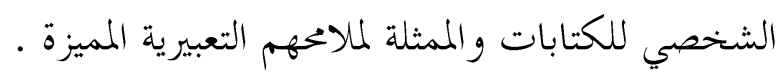

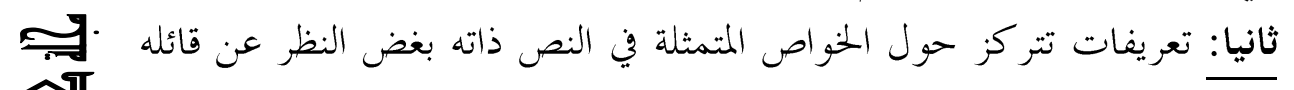
كما تتجسد موضوعيا في الأعمال الأدبية.

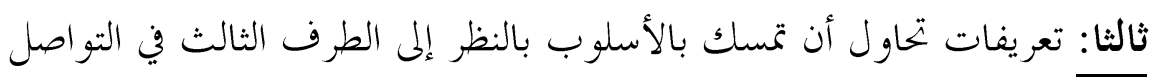

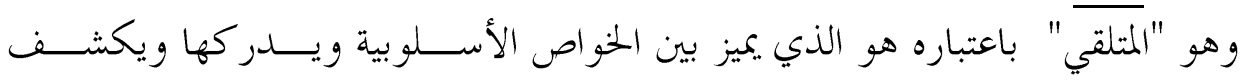

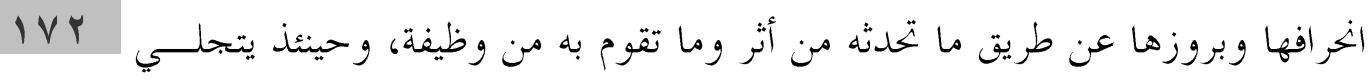

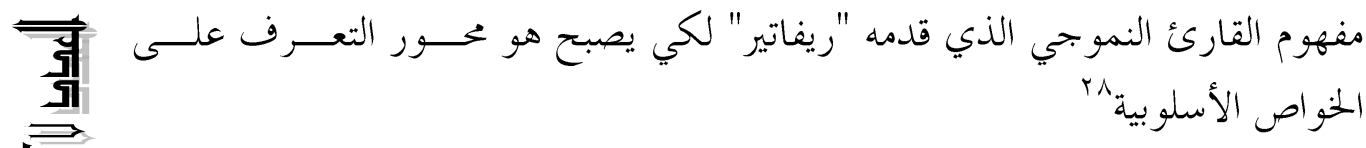

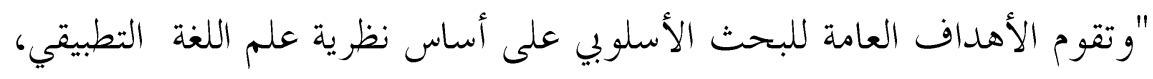

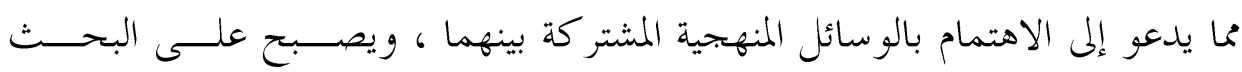

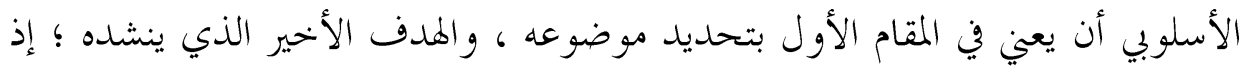

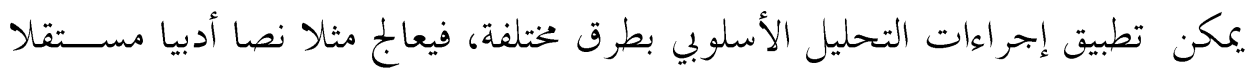

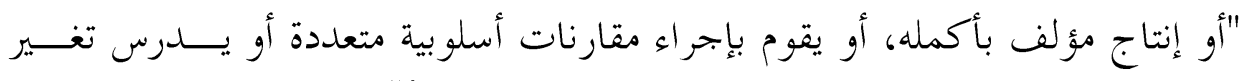

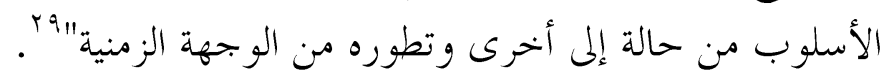

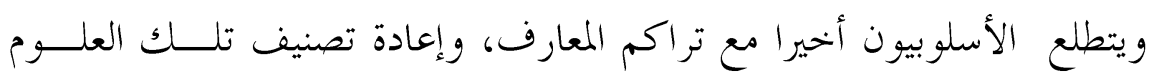

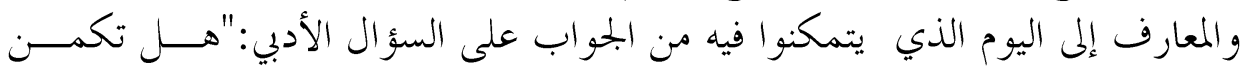




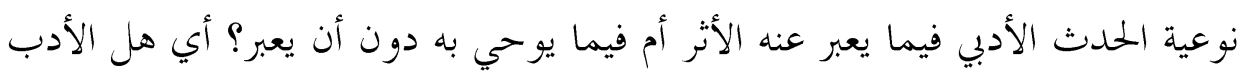

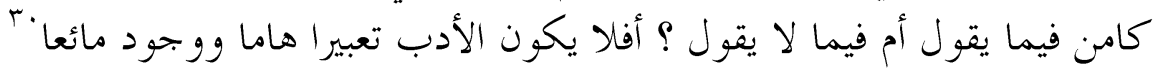

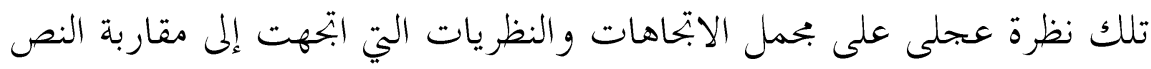

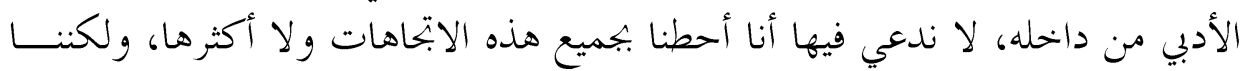

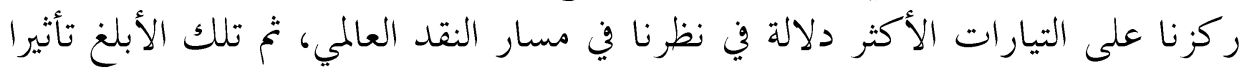
في حصيلتنا النقدية العربية المعاصرة.

\section{ثانيا - استقبال المناهج "النصيتة" في الوطن العربي:}

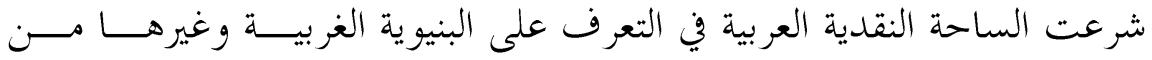

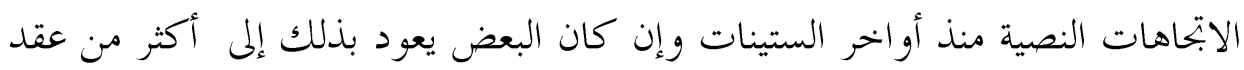

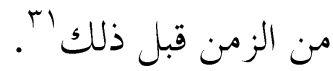

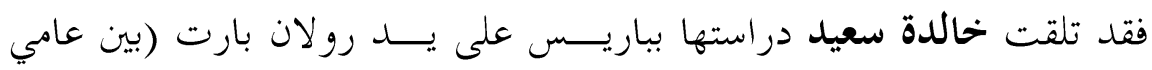

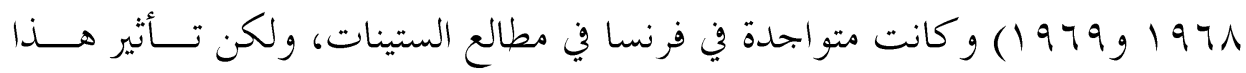

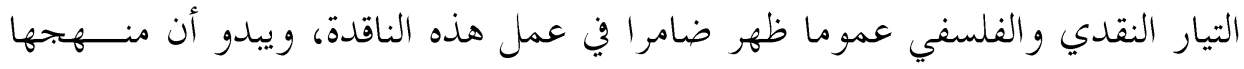

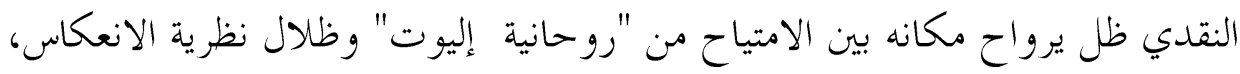

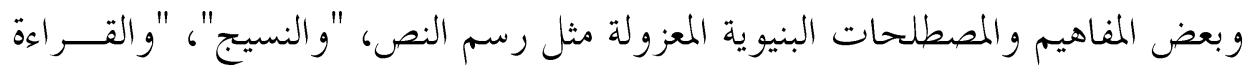
IVT

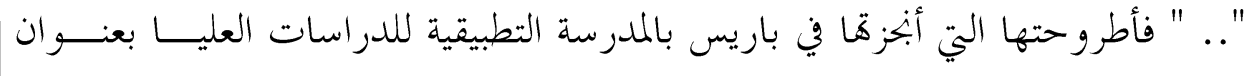

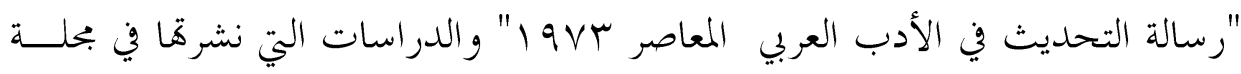

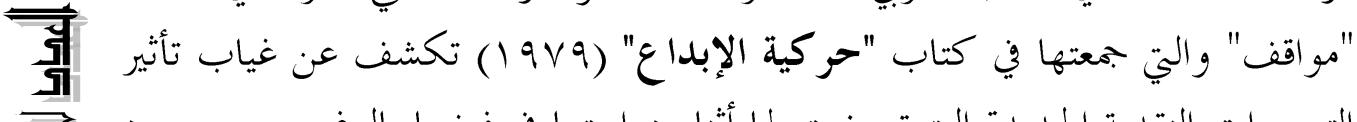

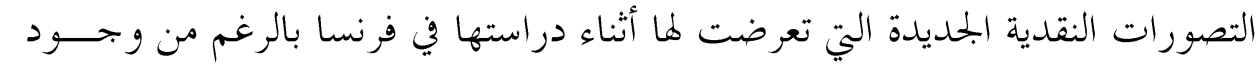

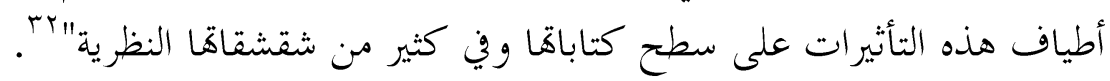

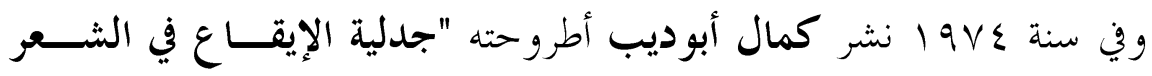

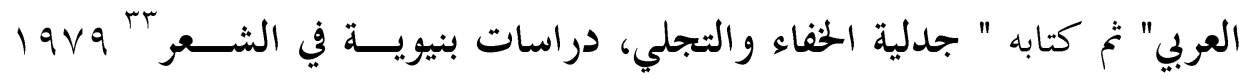
مو اصلا أعماله في هذا السياق خلال "حدل العقود التالية.

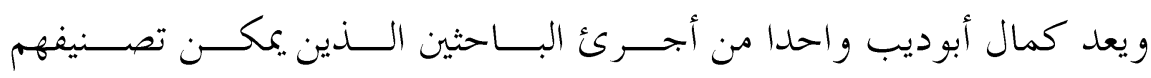

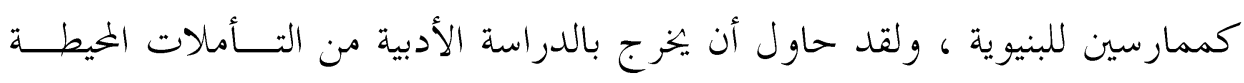

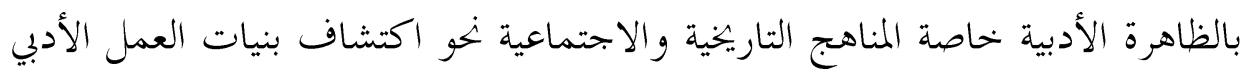


وترصد العلاقات القائمة بين أنساقها، وسعى إلى دراسة مستويات "البنية الســطحية"

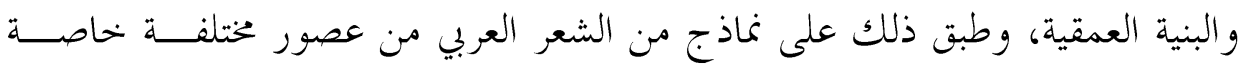

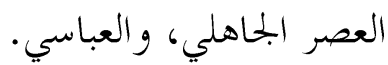

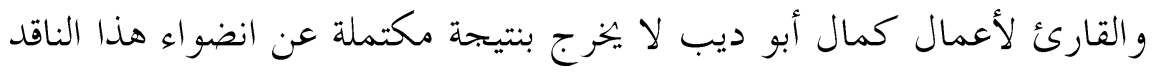

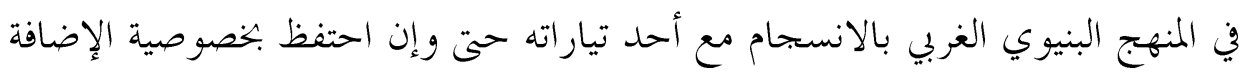

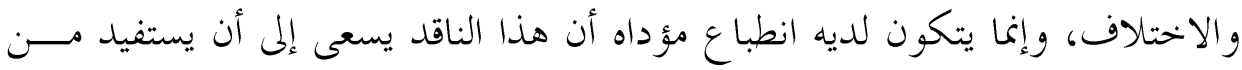

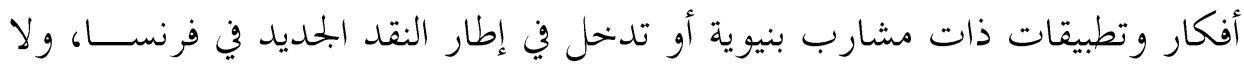

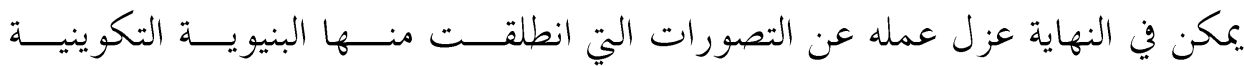
الجولدمانية، وأطروحات لو كاتش المار كسية الجديدة.

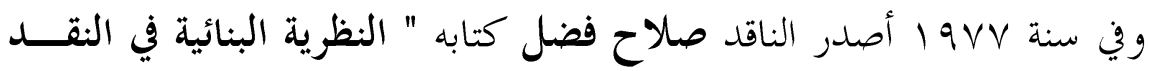

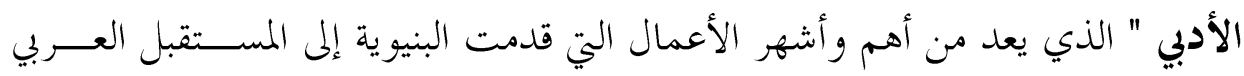

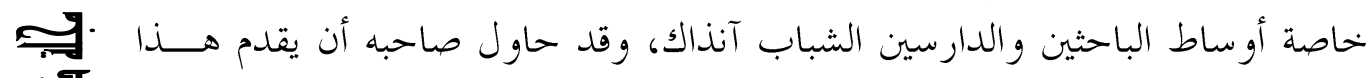

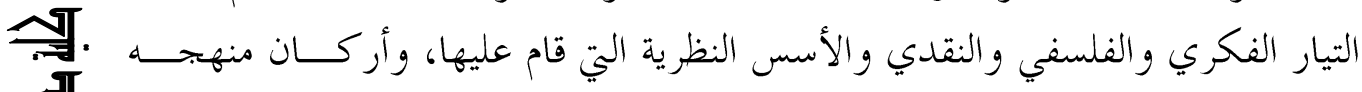
$\stackrel{\frac{\pi}{3}}{=\frac{4}{3}}$ IV

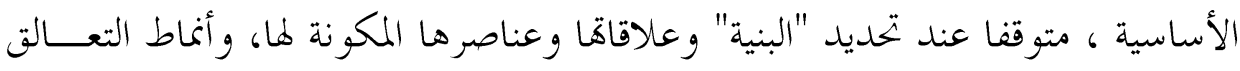

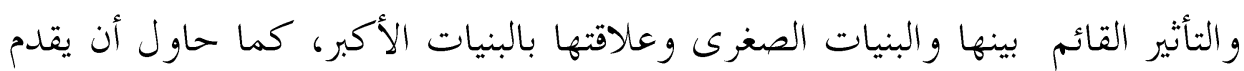

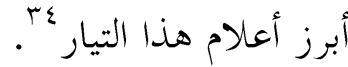

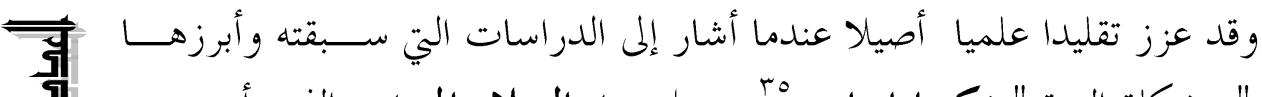

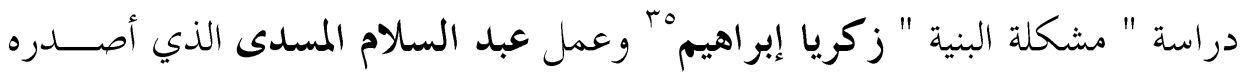

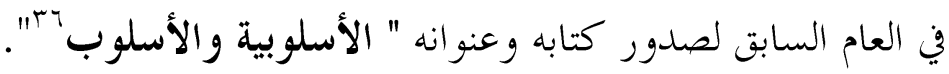

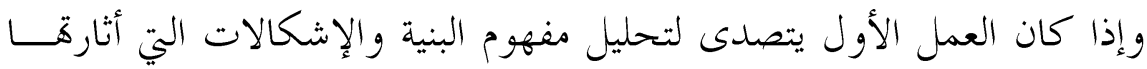

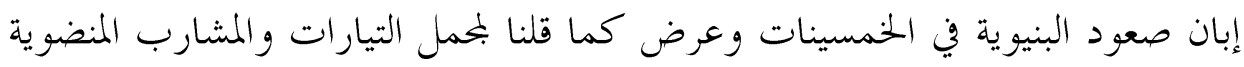

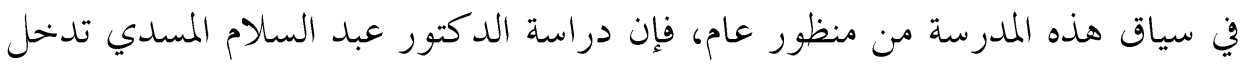

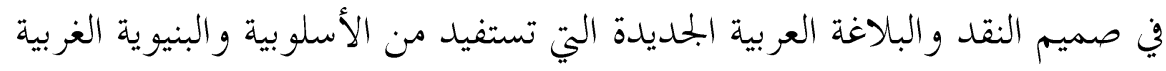

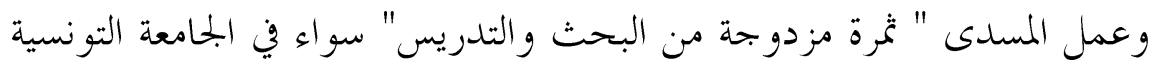

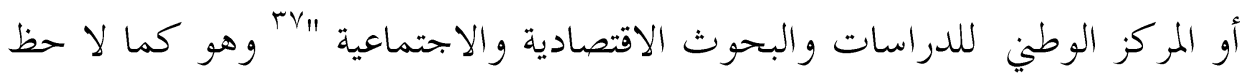

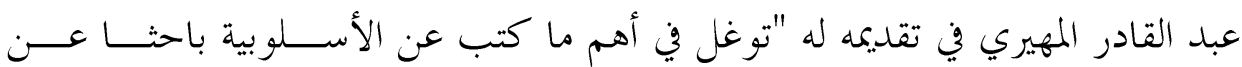




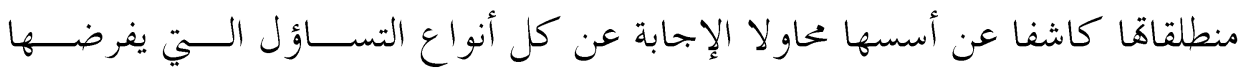

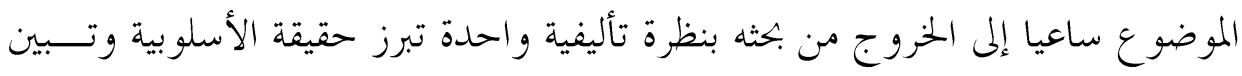

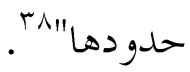

ويبدو أن طموحات المسدى أبعد مدى مما لخص لمهيري، وتتطلــع إلى إقامــة نظرية تحاوزية أقرب إلى القطيعة العلمية:

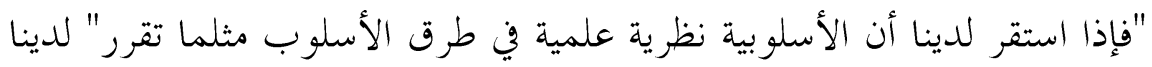

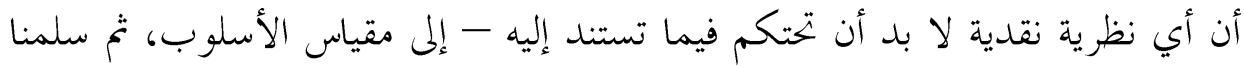

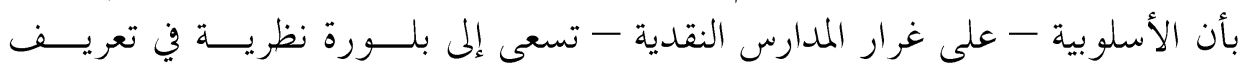

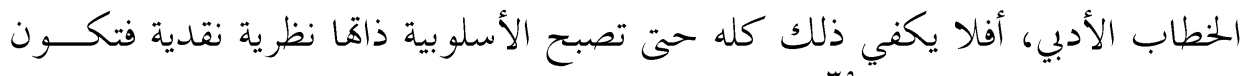

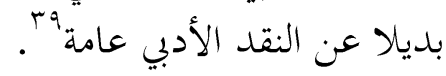

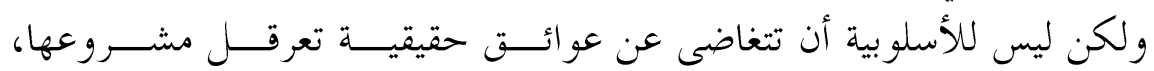

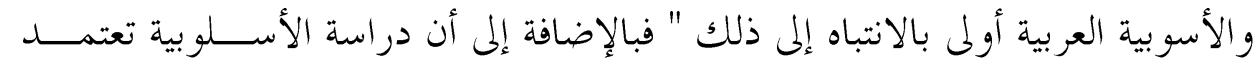

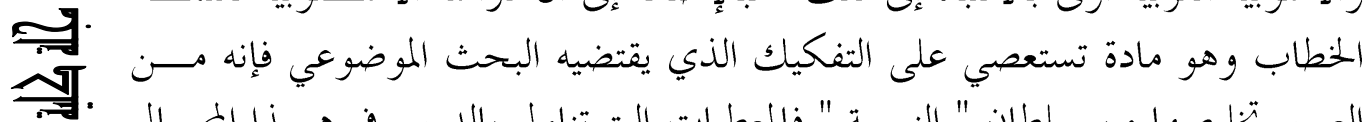

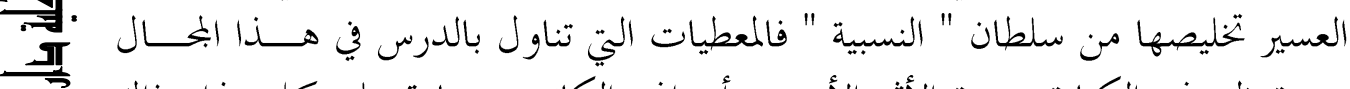

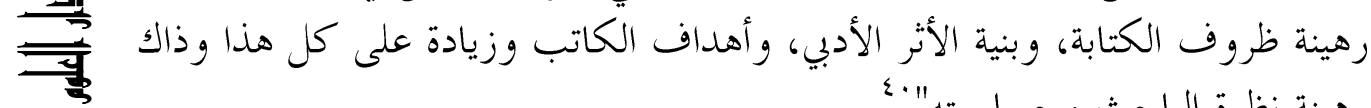

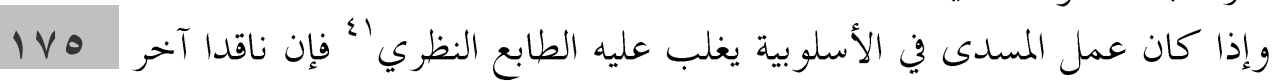

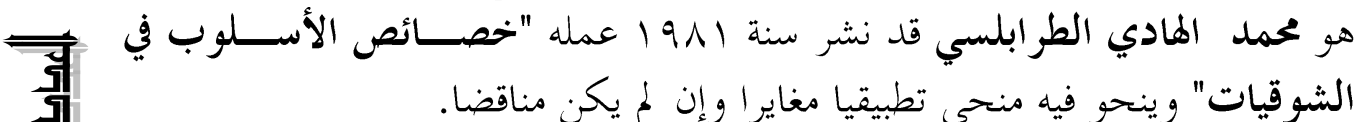

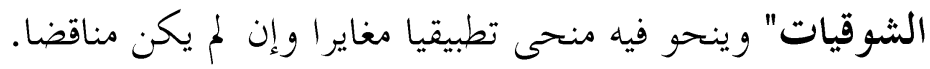

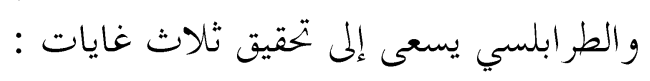

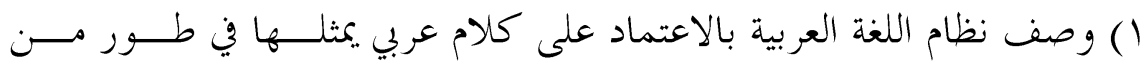

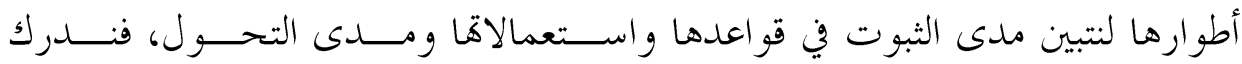
خصائصها المميزة وإمكانيات التطور فيها.

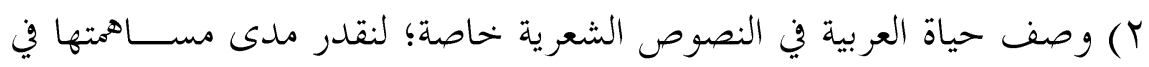

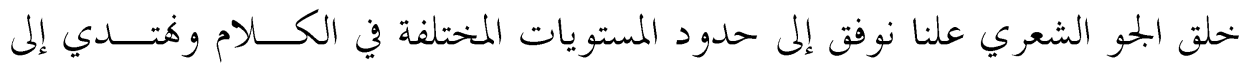
وظائف اللغة المختلفة في بلورة هذه المستويات. 
r) وصف حياة العربية في شعر شاعر معين هو أحمد شوقي لنتبين الحظظ الــــي

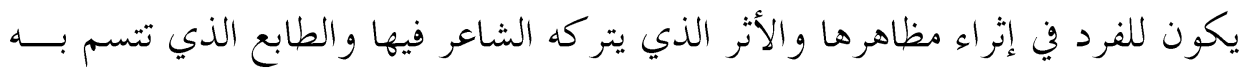

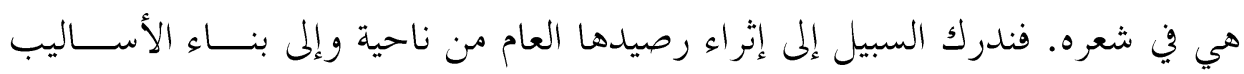

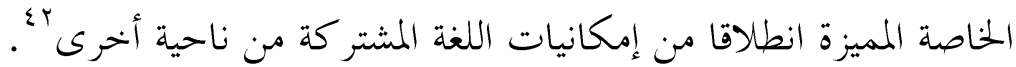

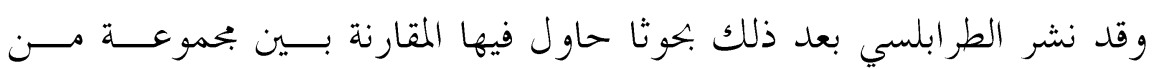

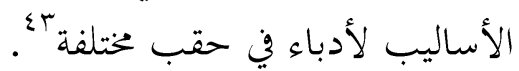

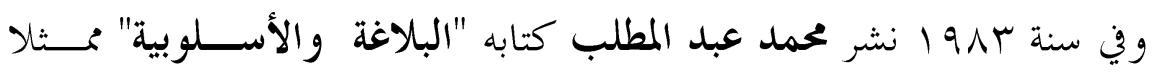

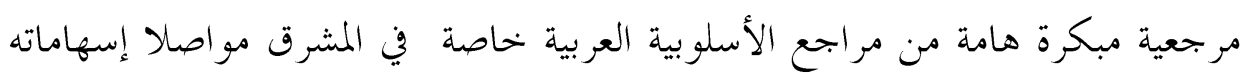

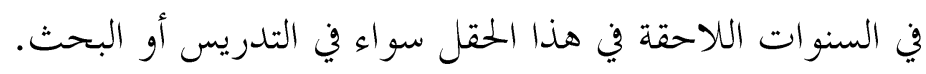

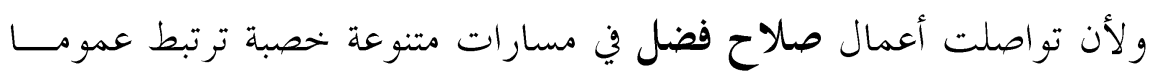

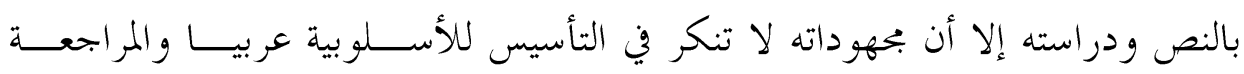

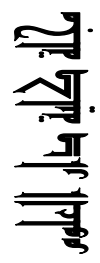

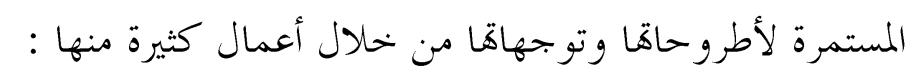

$199 r$

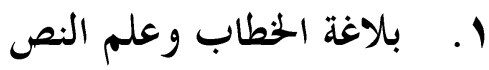

1997 Y. ب أساليب الثعرية العربية

1991

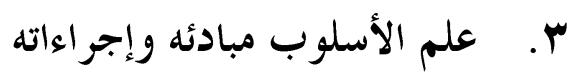

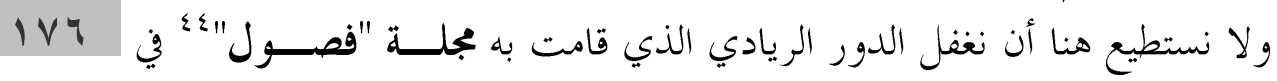

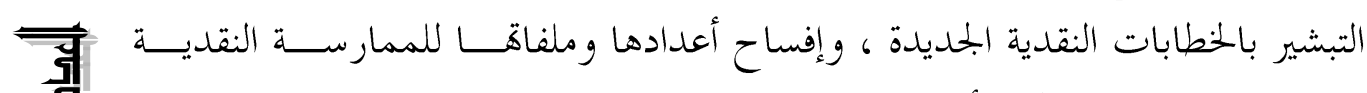

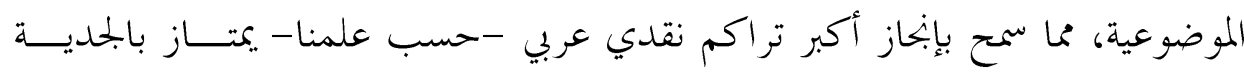

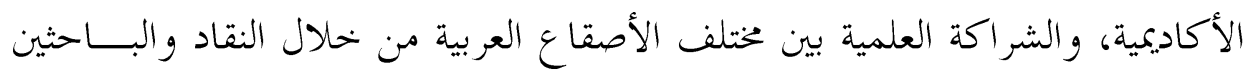

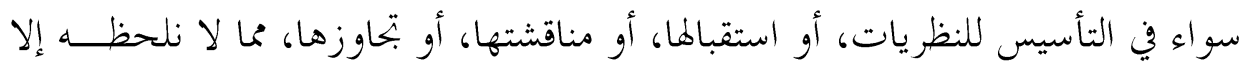
في نظيرات لها في البلاد الغربية لا تكاد تصل أصابع اليد.

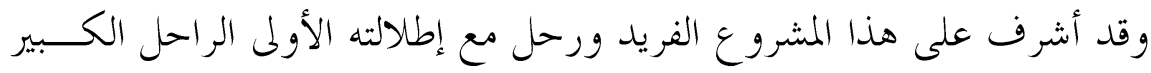
الشاعر "صلاح عبد الصبور"، وواصله بصبر ونشاط وبتحيد دائب الناقد المنظر "عز إعز

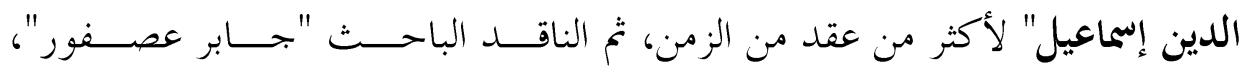

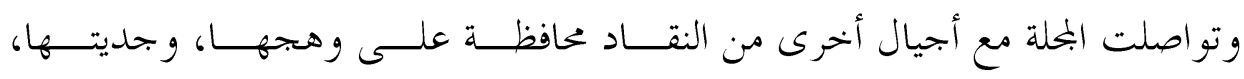

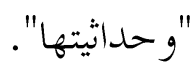




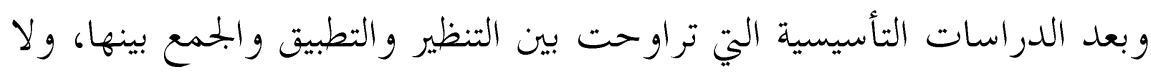

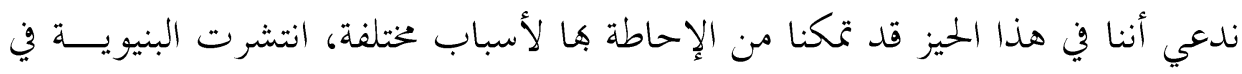

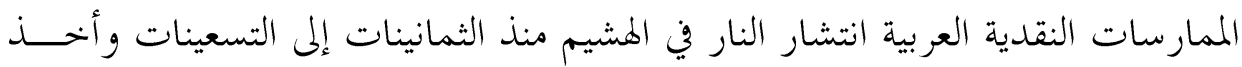

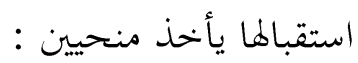

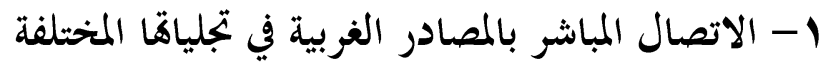

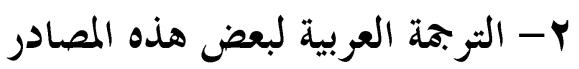

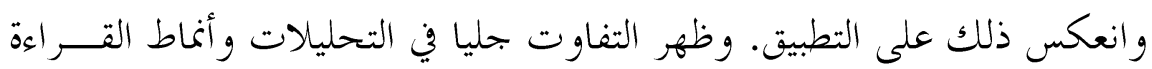

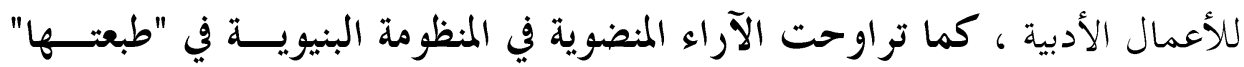

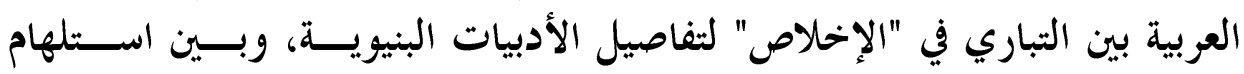

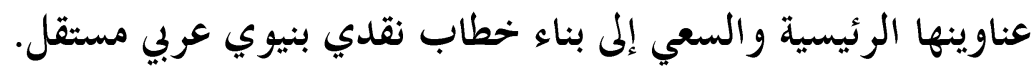

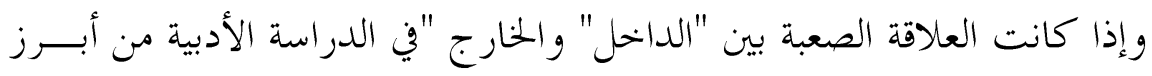

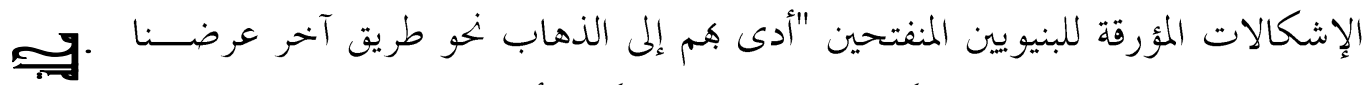

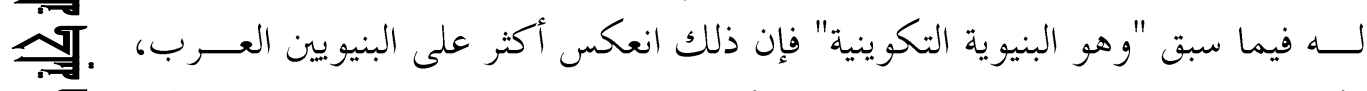

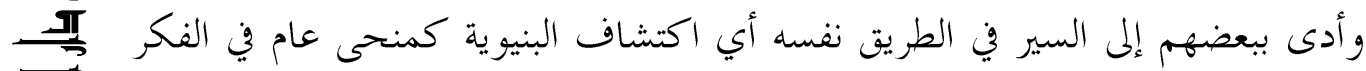

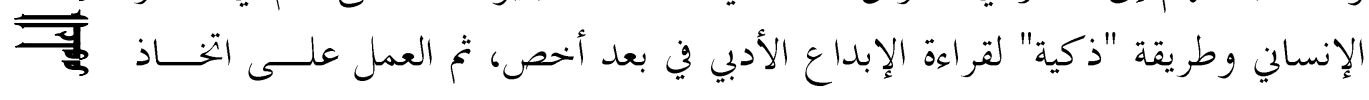

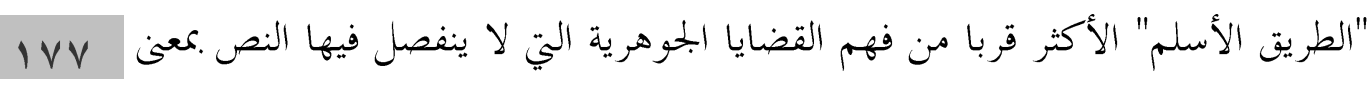

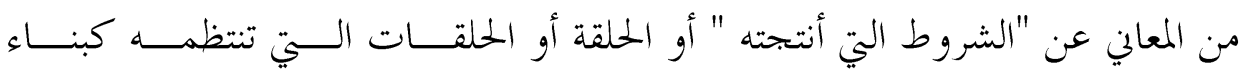

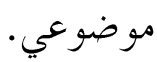

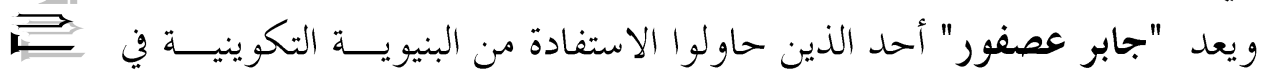

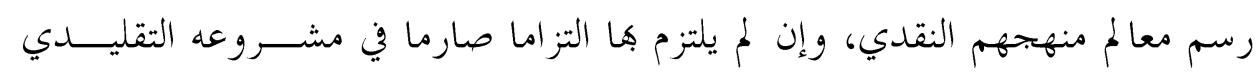
المديد.

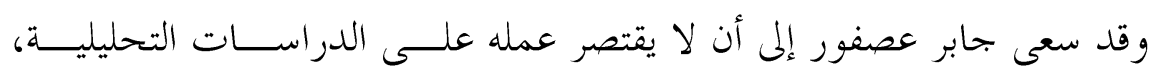

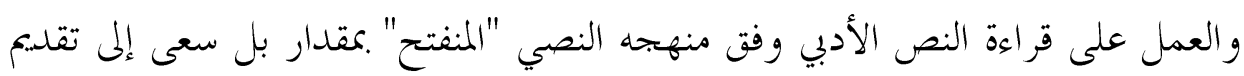

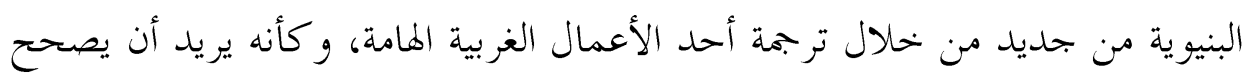

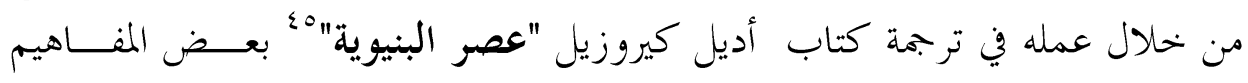

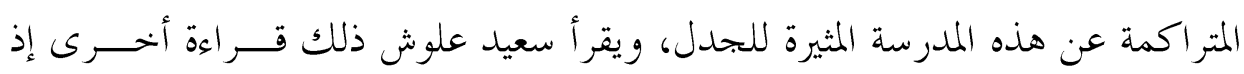




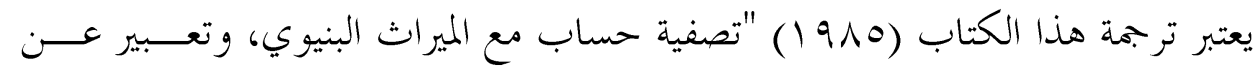

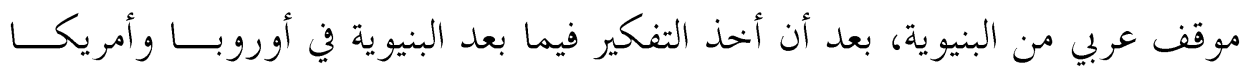

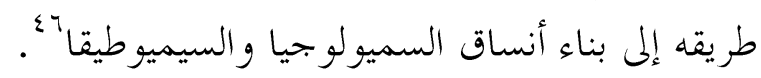

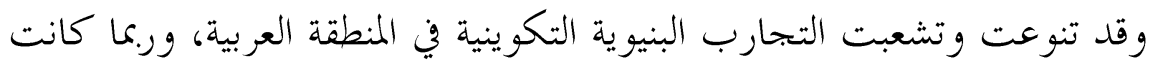

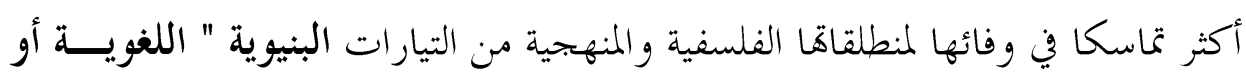
الشكلية " كما يسميها البعض في البلاد العربية.

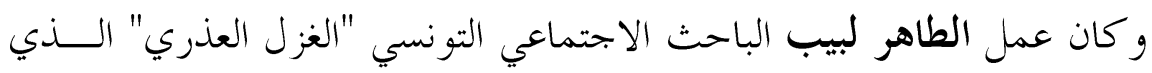

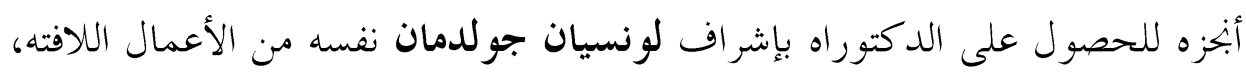
وقد درس ظاهرة الغزل العذري في العصر الأموي من ناحية تعبيرها عن رؤية العــــالم

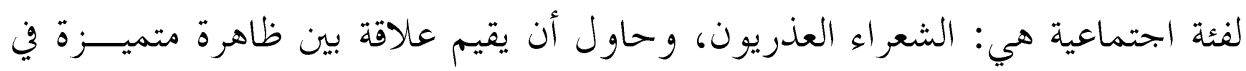

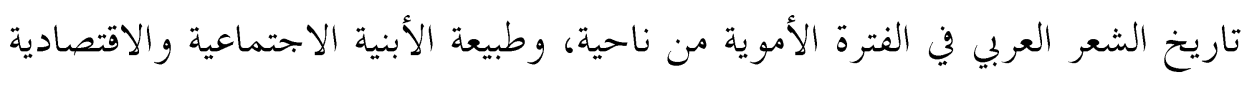

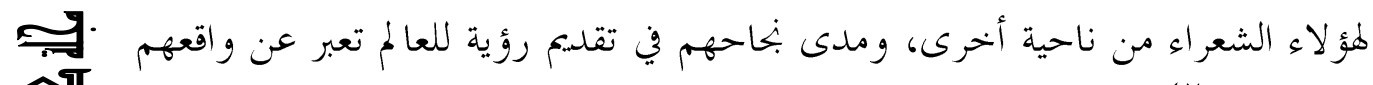

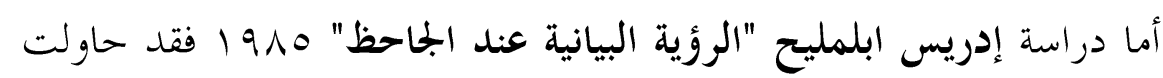

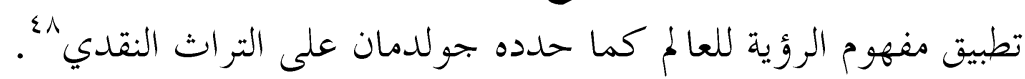

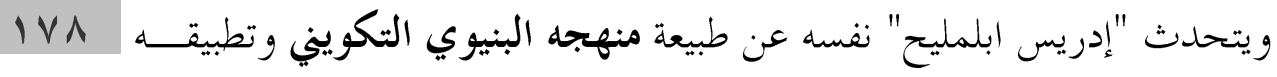

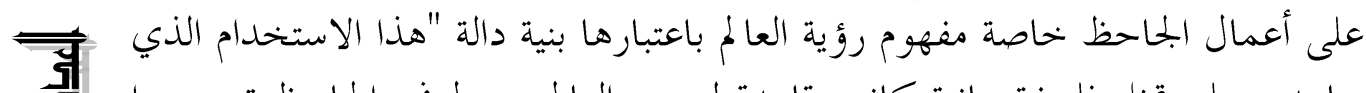

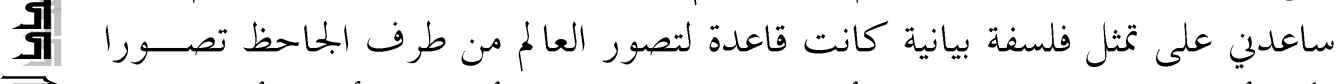

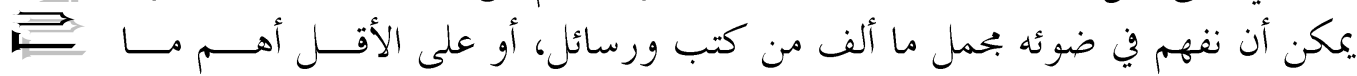

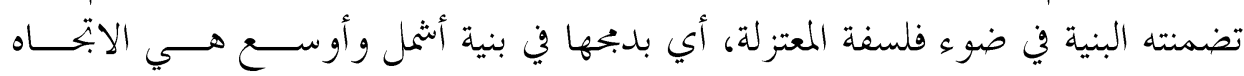

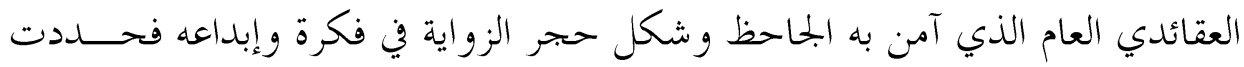

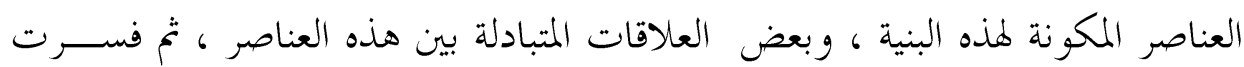

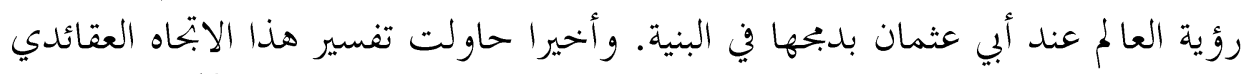

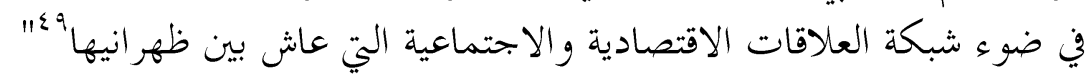

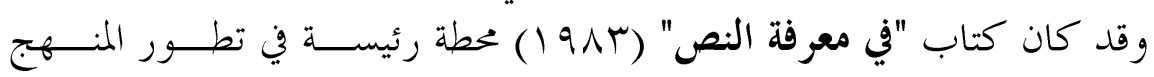

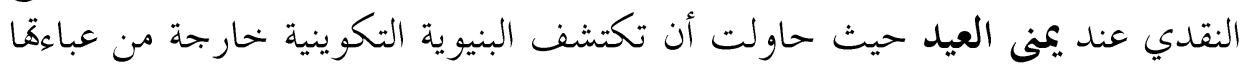


الماركسية الصرفة التي ظهرت من خحلال معظم أعمالها الســابقة خحاصـــة " الدلالــــة

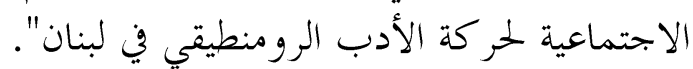

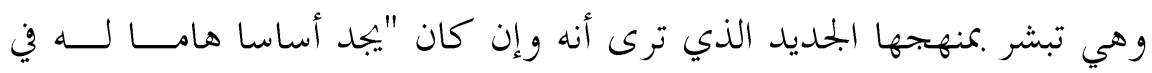

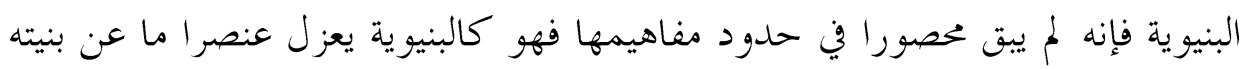

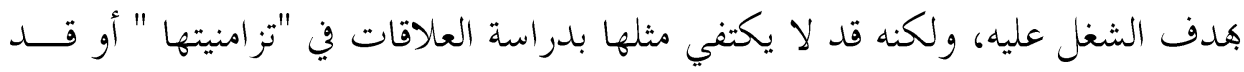

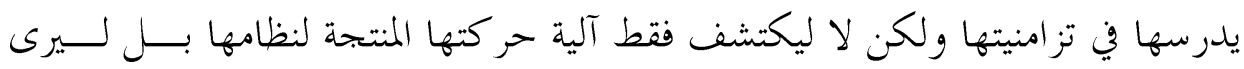

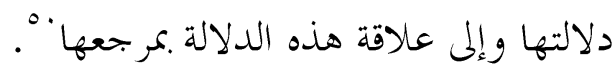

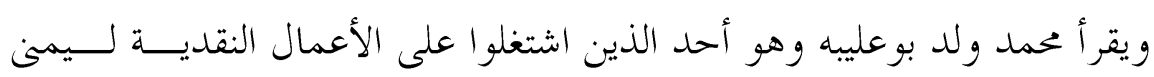

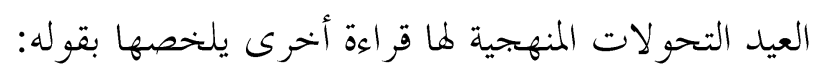

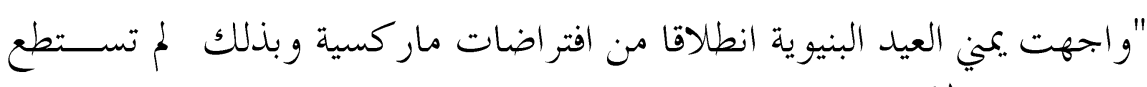

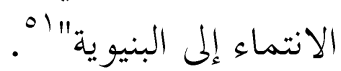

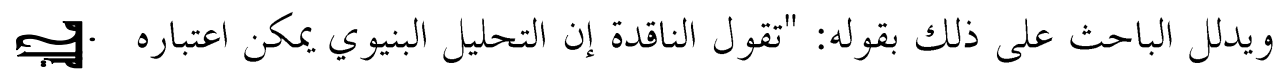

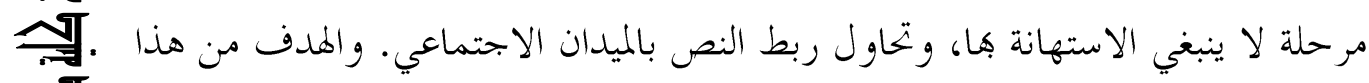
$\frac{\frac{\pi}{5}}{=\frac{4}{3}}$

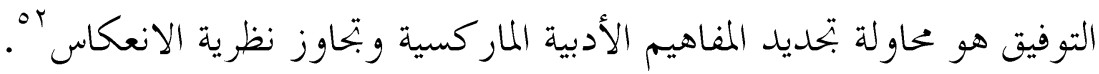

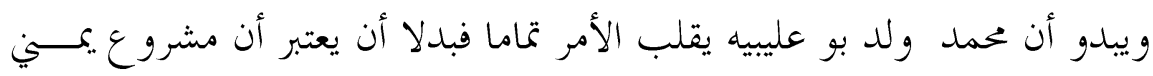

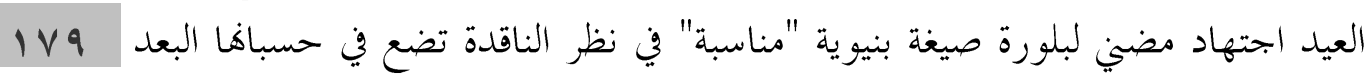

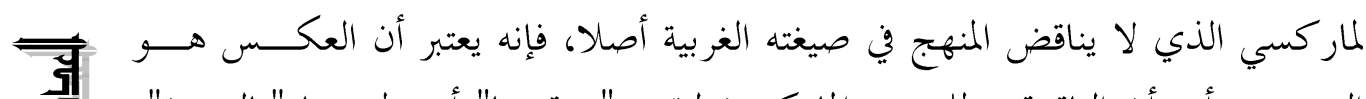

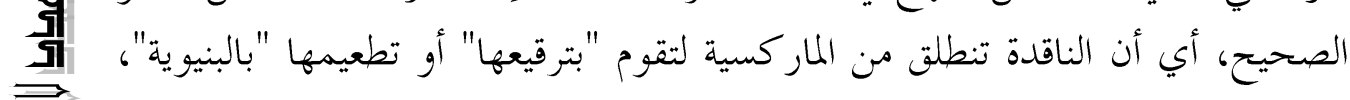

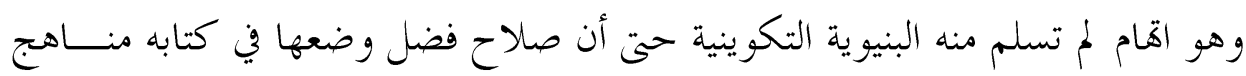

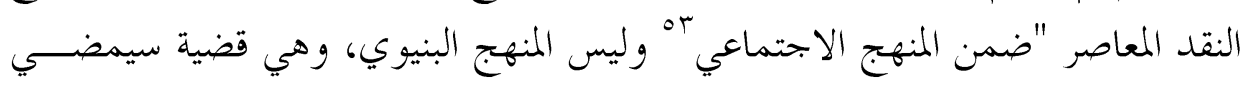

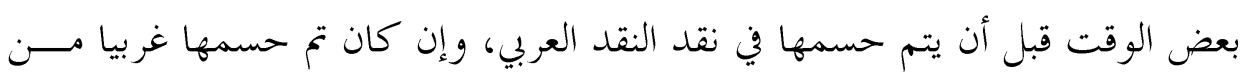
زمن غير قريب.

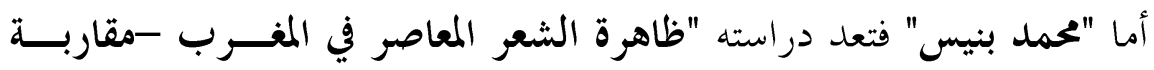

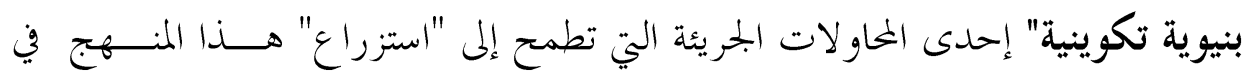

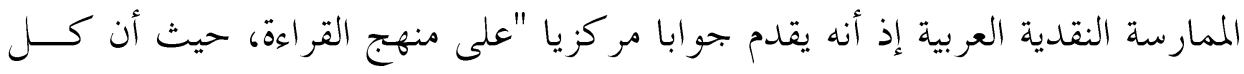

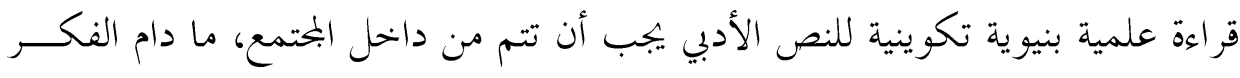


والإبداع جزءا من الحياة الاجتماعية، و ما دامت للنص الأدبي وظيفة محددة تاريخيا، إذ إذ إنئ

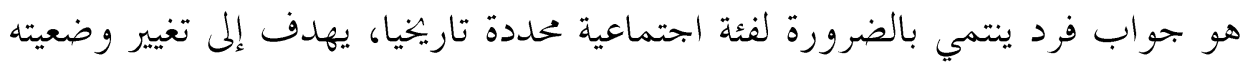

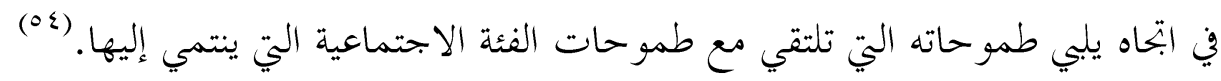

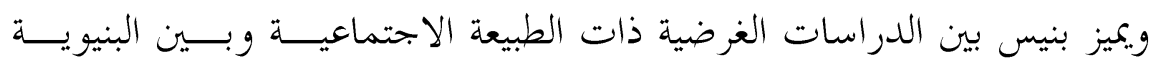

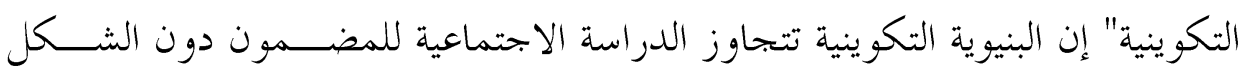

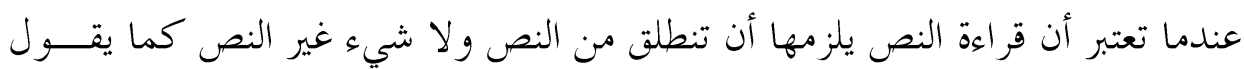

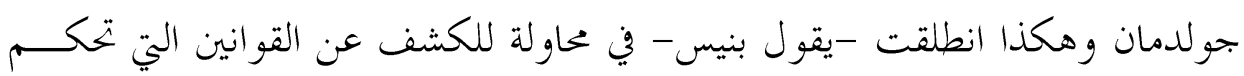

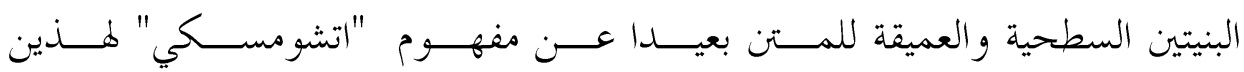
المصطلحين (م) البنينين (1)

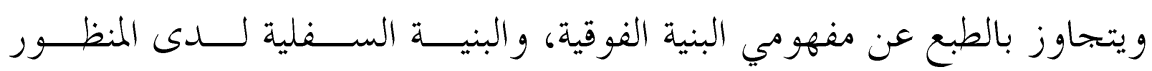
المار كسي.

و تظهر هذه الاستراتيجية، في التوزيع المنهجي للخة العمل في ثلاثة أبواب :

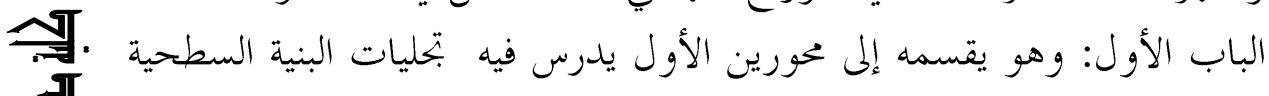
$\frac{\pi}{\frac{4}{3}}$

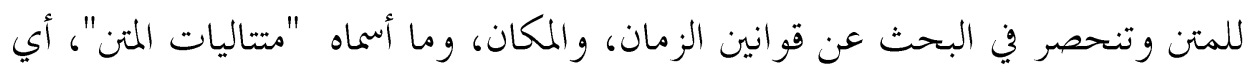

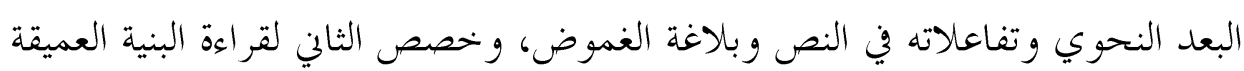

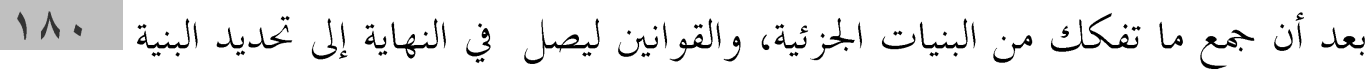
الباب الثاني: وهو ارتفاع بالقراءة من داخل المتن إلى خحارجه في الجحال الثتــافي و الشعري خاصة في المغرب. الباب الثالث: وفيه "(تم) إدخال البنية الداخلية للمتن والبنية الخنارجية المتعلقـــة

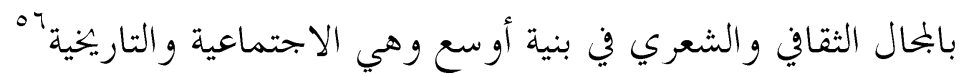

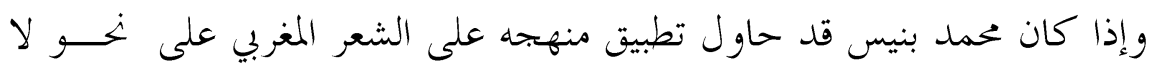

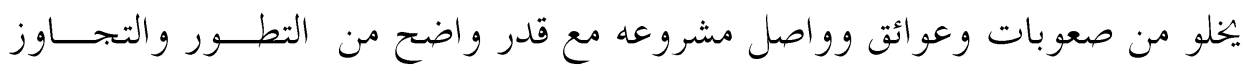

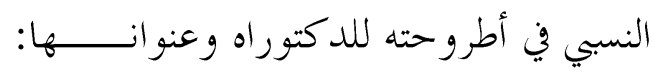

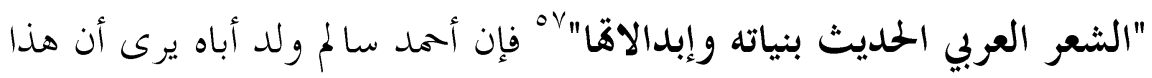

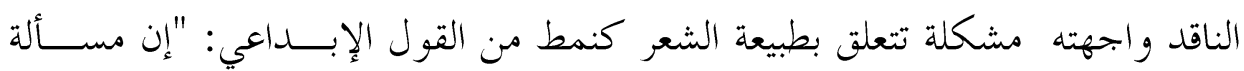


الأبنية الشعرية المكتتزة والمكتفة" تبقي دائما أقل فاعلية وأكثر صعوبة من تحليل بنيـــة

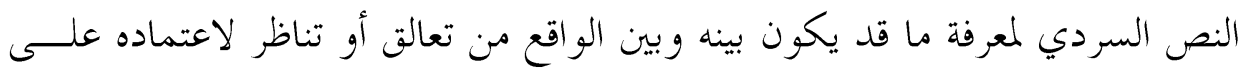

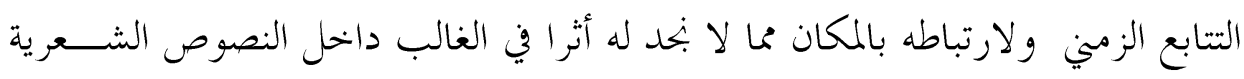

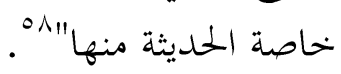

وهو يعتبر أن هذا العائق المفصلي قد ساعد "حميد لحمداين" حينما طبق هــــــا

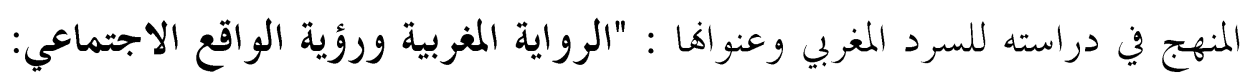

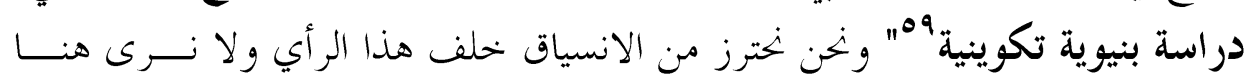
المحال مناسبا لمناقشته أو الحكمي عليه.

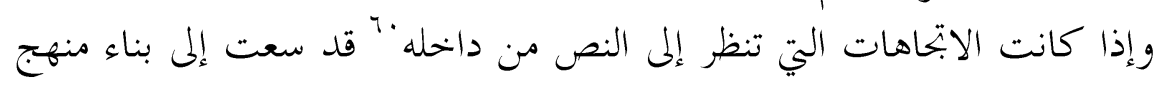

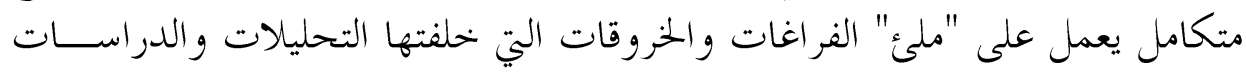

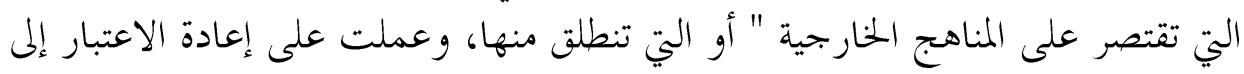

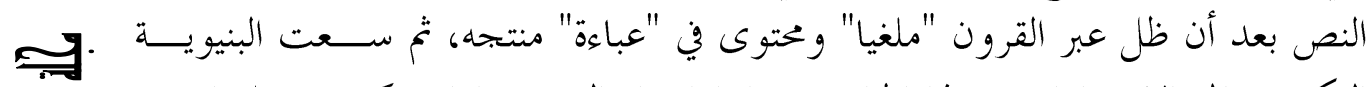

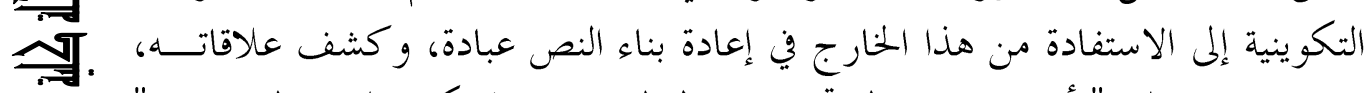

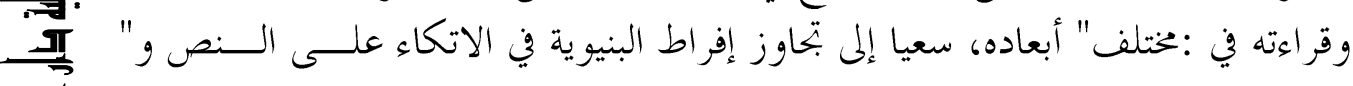

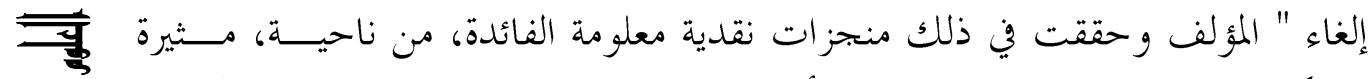
$1 \wedge 1$

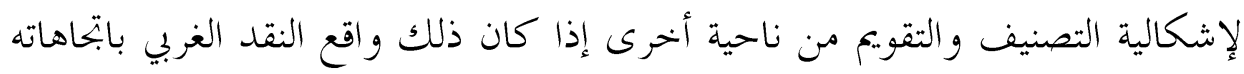

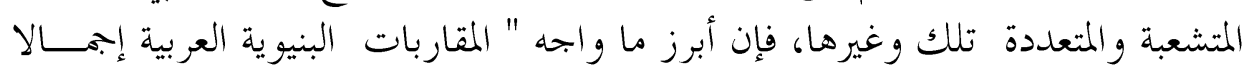

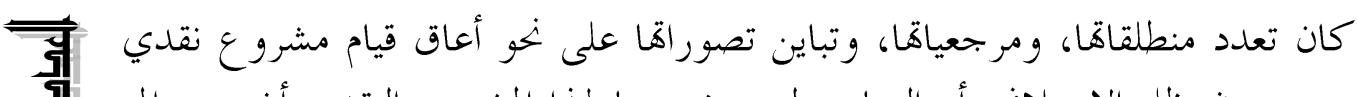

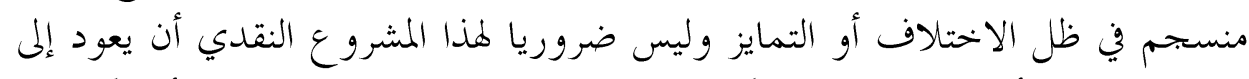

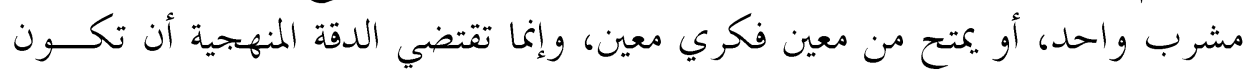

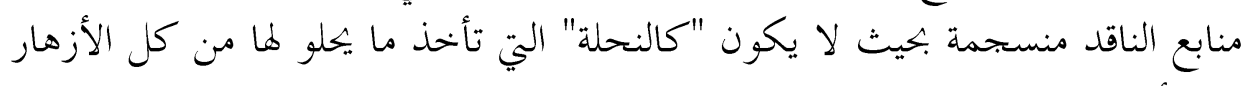

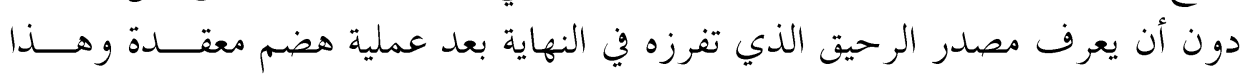

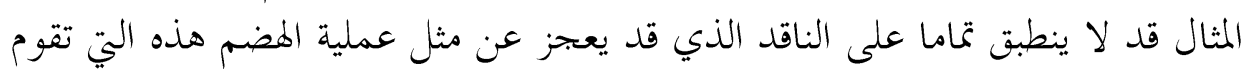

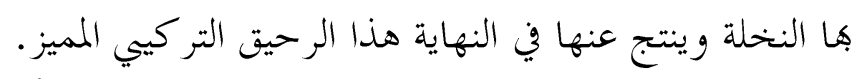

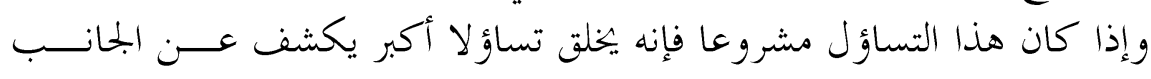

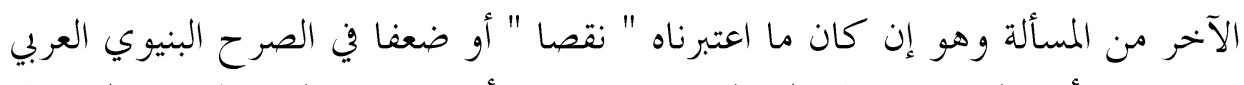

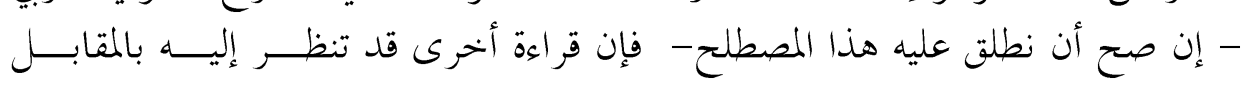


باعتباره محمدة، وغنى، وتعددا في الرؤى والتجارب، وهي إشكالية لن يتم حســمها بسهولة.

\section{الهوامش}

' - فردنان دي سوسير : دروس في اللسانيات العامة، ترجمة صالح القرمادي، الدار العربيــة

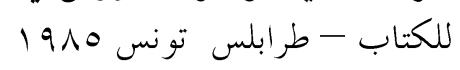

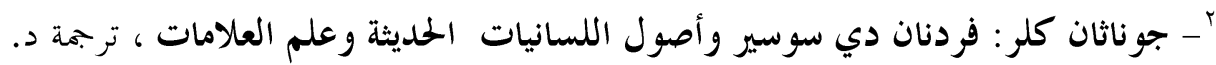

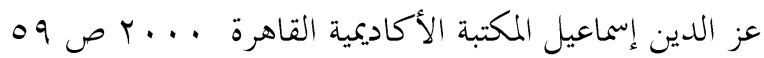

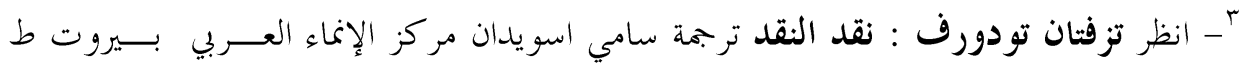

$$
\text { ا }
$$

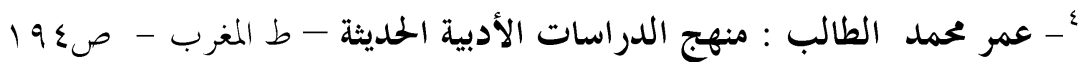

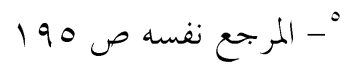

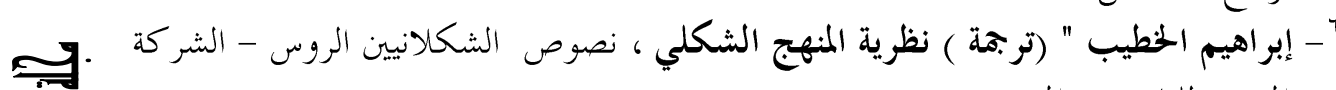

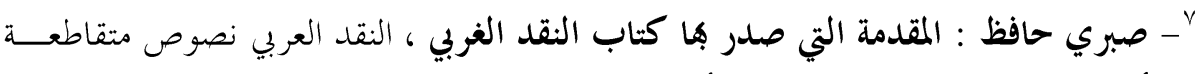

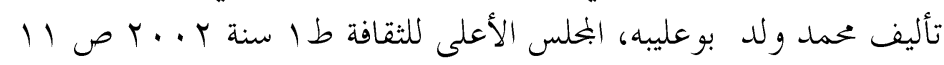

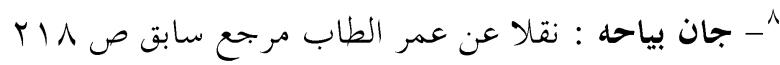

$1 \wedge r$

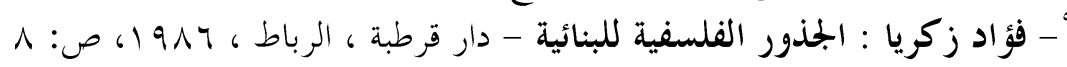

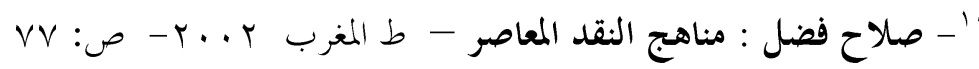
V V

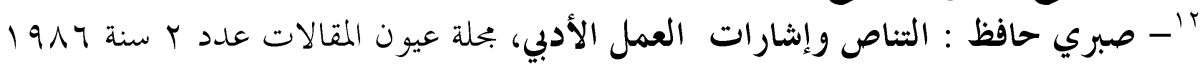
ص :

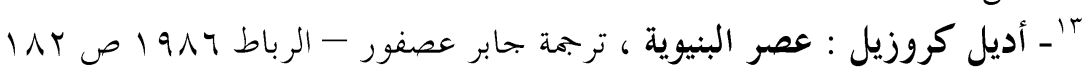

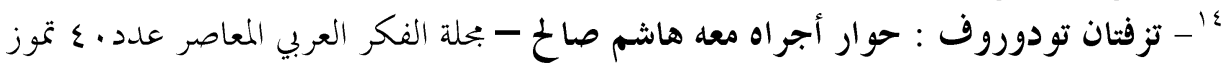

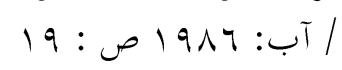

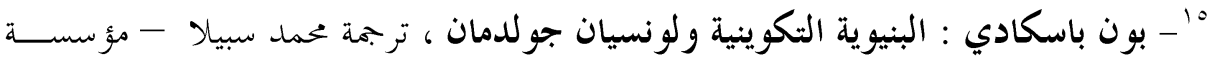

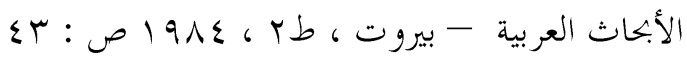

$$
\begin{aligned}
& \text { 17 - المرجع نفسه و الصفحة نفسها }
\end{aligned}
$$

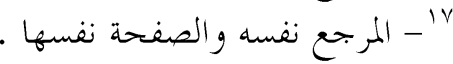

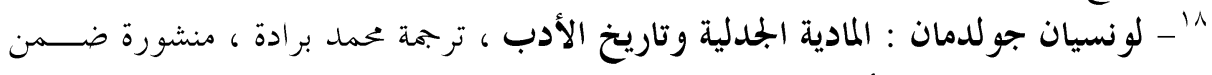

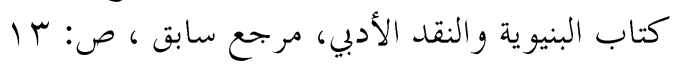




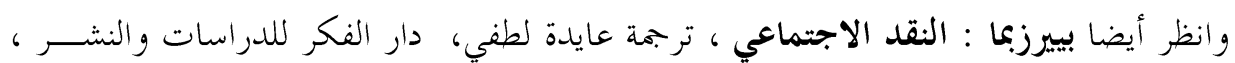

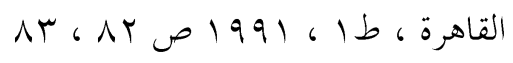

TrV

$$
\text { r. }
$$

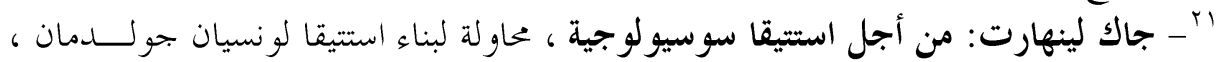

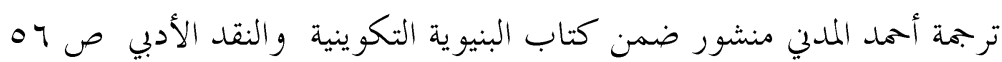

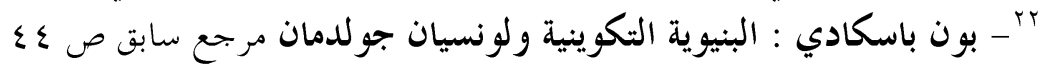

$$
\text { ك }
$$

r

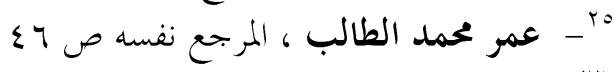

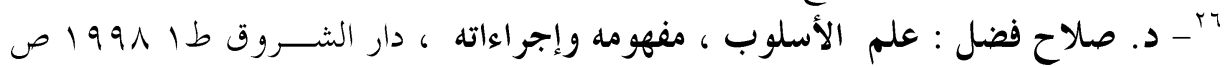

Tr

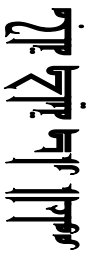

$$
r \cdot \text { r } 1914
$$

ل

| 1 19 :

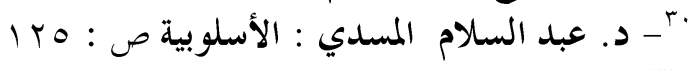

IA

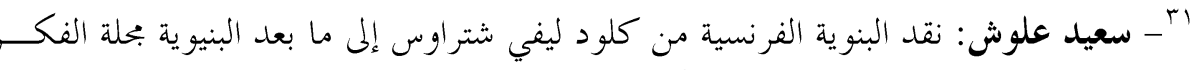

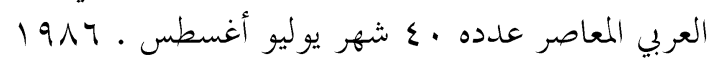

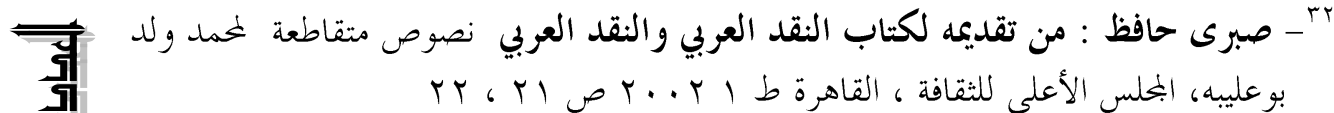

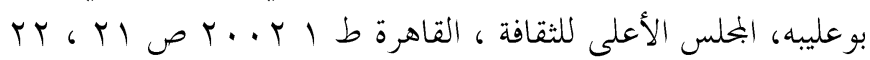

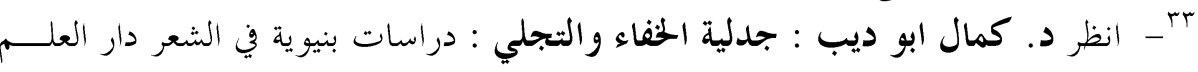

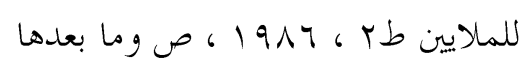

ع ع - د ـ صلاح فضل : النظرية البنائية في النقد الأدبي - انظر مثلا طبعة مكتبة الأبخلو المصرية

191.

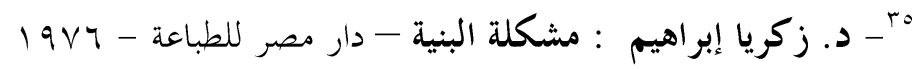

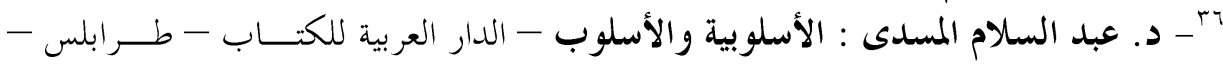

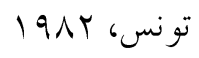

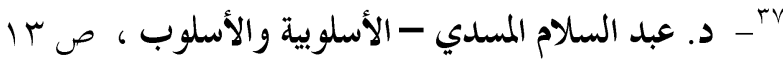

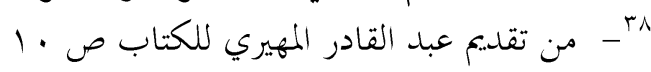

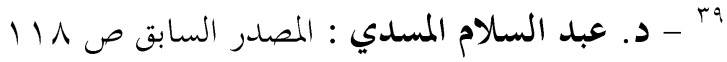




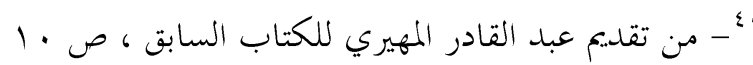

اء- قام المسدي بإبحاز دراسات تطبيقية منها بكثه: التضافر الأسلوبي وإبداعية الشعر، منشئسـور

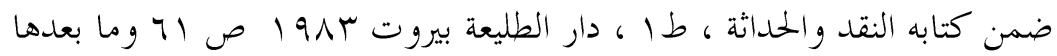

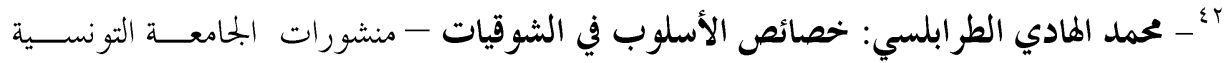

بــ محمد الهادي الطرابليسي : شعر على شعر - معارضات شوقي .منهج الأسلو بية المقارنـــة

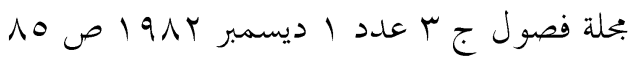

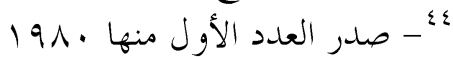

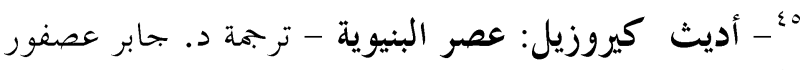

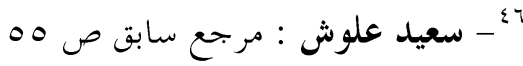

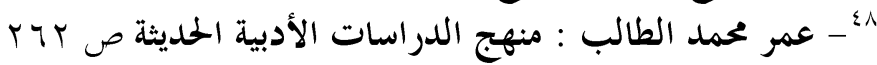

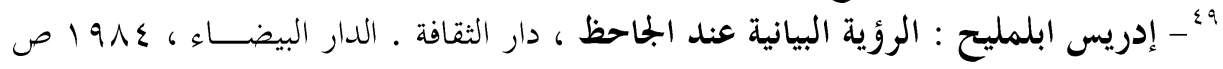

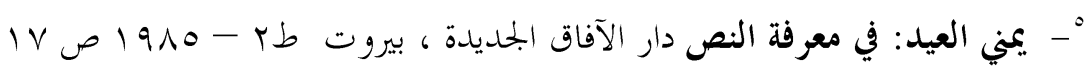

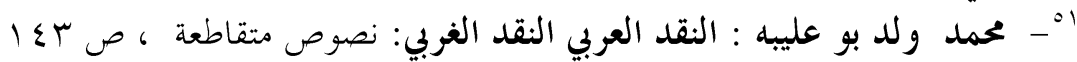

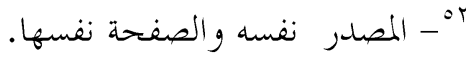

ك

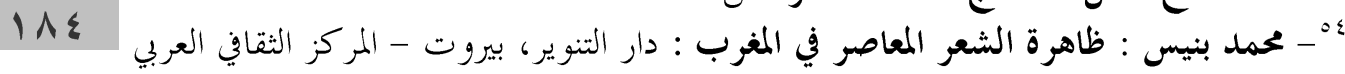

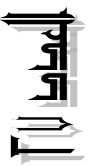

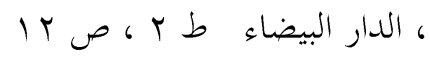

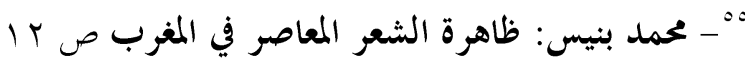

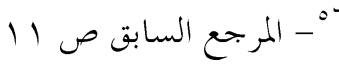

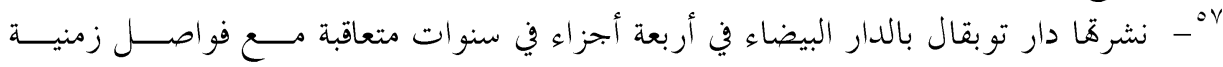
متفاو تة.

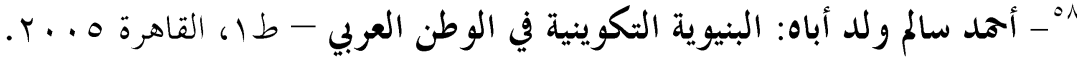

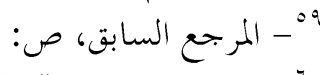

•T - و يسميها البعض "الاتجاهات النصية وقد أطلقنا عليها أحيانا هذا المصطلح حيث لم بجدا مانعا

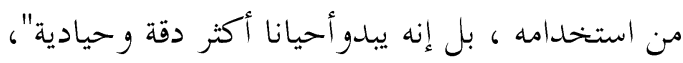

